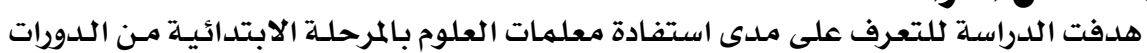

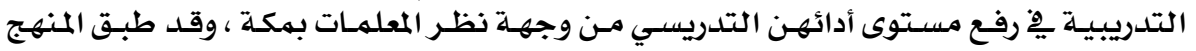

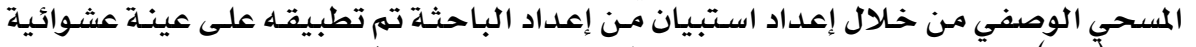

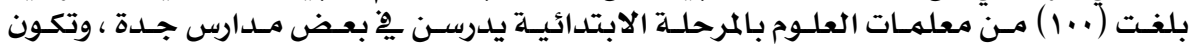

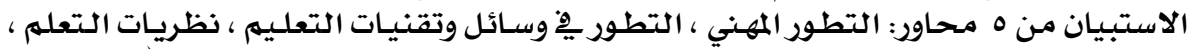

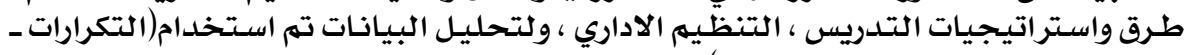

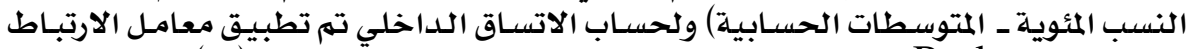

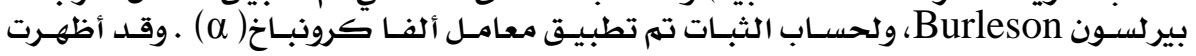

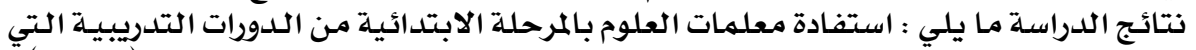

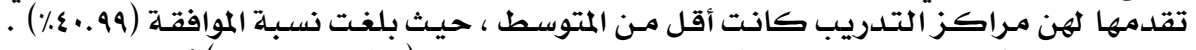

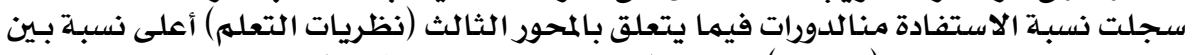

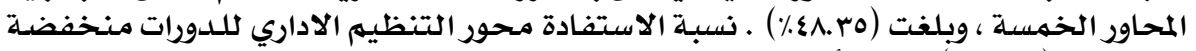

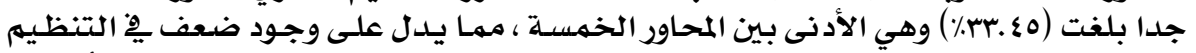

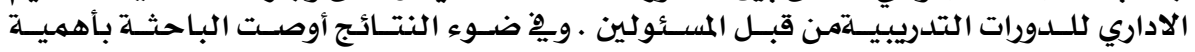

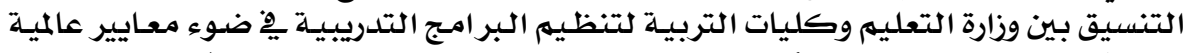

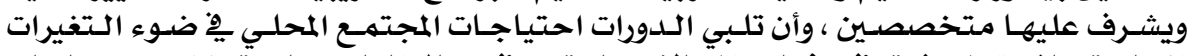

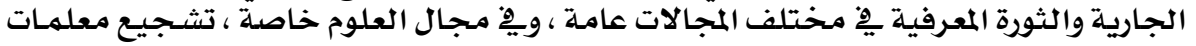

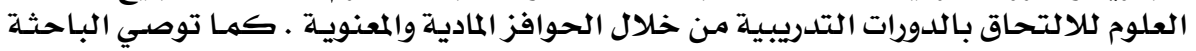

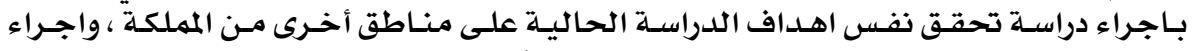

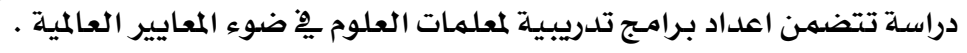

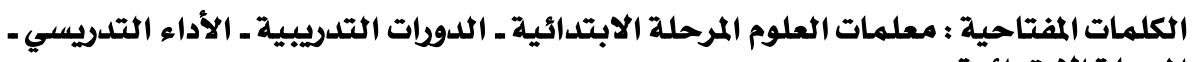
المرحلة الابتدائية.

The Extent Benefit of Science Teachers for Training Courses in Elementary Stage in Raising the Level of Their Performance Teaching from the Perspective of Teachers in Makkah

\title{
Dr. NissreenHasanSubahi
}

\section{Abstract :}

This study aimed to identify the extent benefitof science teachers for training courses in elementary stage in raising the level of their performance teaching from the perspective of teachers in Makkah, and the survey method descriptive dish by preparing a questionnaire prepared by the researcher has been applied to a random sample of (100) of the phase parameters primary studying in some schools Jeddah, and be the questionnaire of 5 axes: professional development, development of the tools and techniques of

\section{MVV}


education, learning theories, methods and strategies of teaching, organization and administrative, and data analysis was used (duplicatespercentage-averages) To calculate the internal consistency was applied Burleson Burleson correlation coefficient, and the expense of stability was applied Cronbach's alpha coefficient $(\alpha)$. The results showed the following : The benefit of science teachers at the elementary stage of training courses offered by the training centers was less than average, reaching approval ratio (40.99\%). An utilization rate of courses to the third axis (learning theories) the highest percentage among the five axes, and was (48.35\%). The rate of benefit forAdministrative regulation was very low, was (33.45\%), the lowest among the five axes, which indicates a weakness in the administrative organization of the training sessions by officials. In light of the findings the researcher recommended the importance of coordination between the Ministry of Education and the colleges of education to organize training programs in the light of international standards and are supervised by professionals, and meet courses needs of the local community in the light of ongoing changes and cognitive revolution in various public areas, and in particular science, encourage science teachers to attend courses training through the material and moral incentives. The researcher also recommends a study achieve the same objectives of the present study to other areas of the $K S A$, a study involving the preparation of training programs for teachers of science in light of international standards.

• الاقدهمة

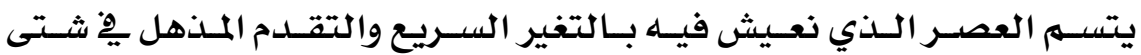

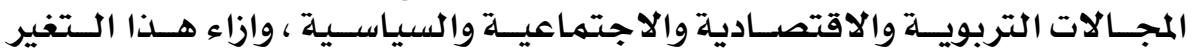

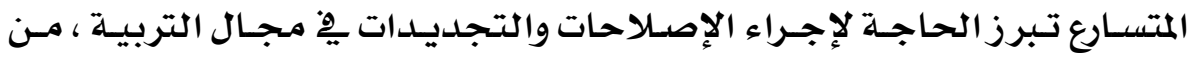

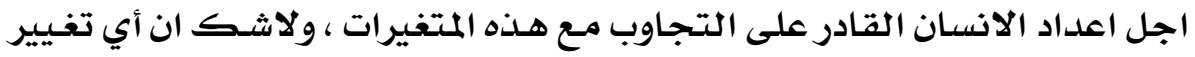

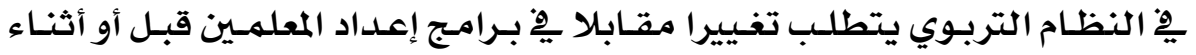

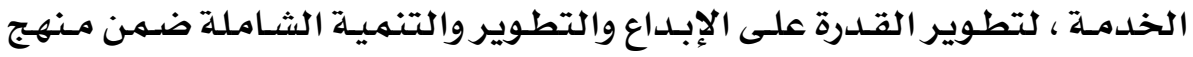

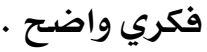

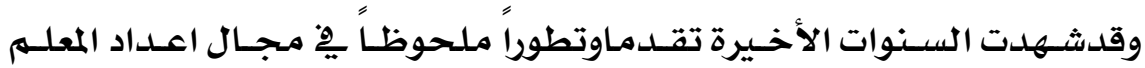

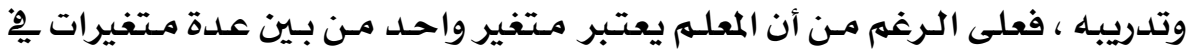

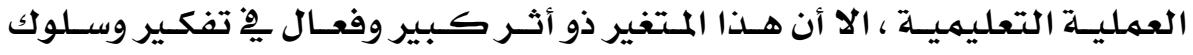

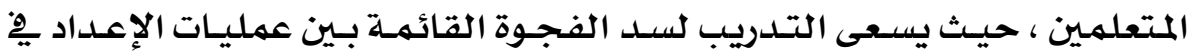

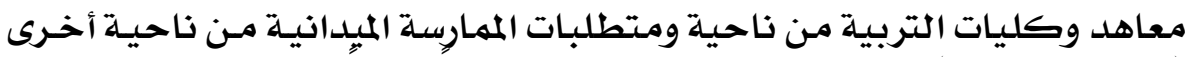

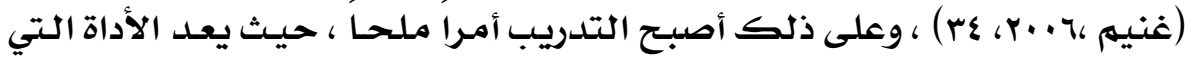

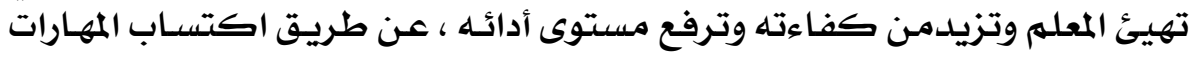

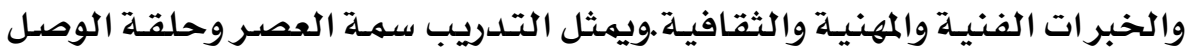

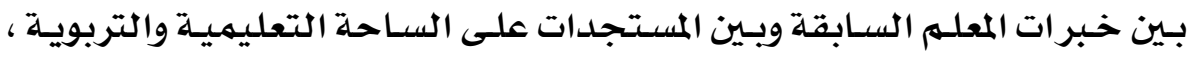

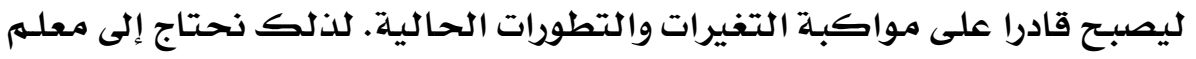

\section{rVA}




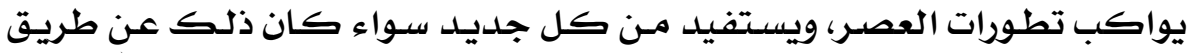

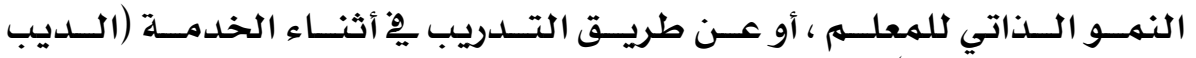

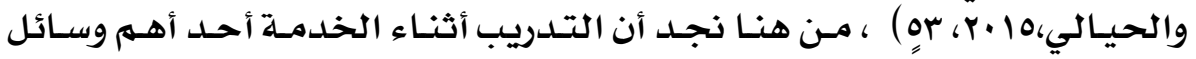

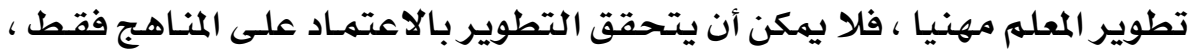

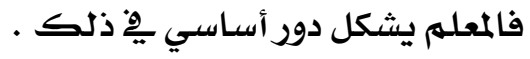

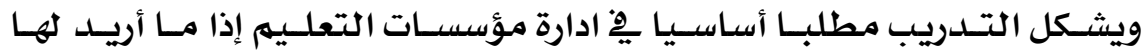

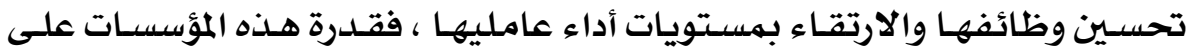

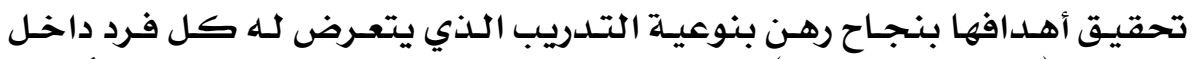

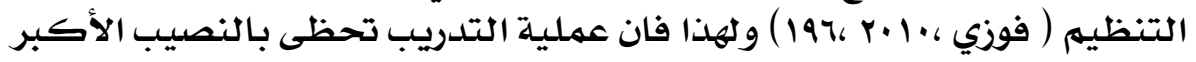

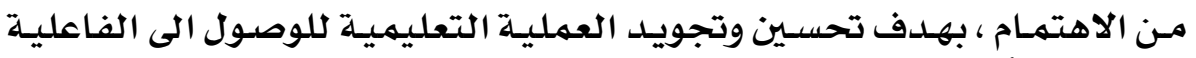

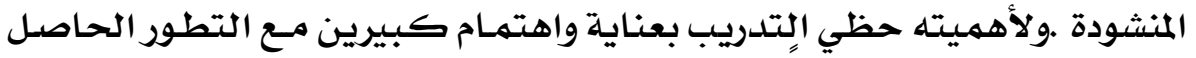

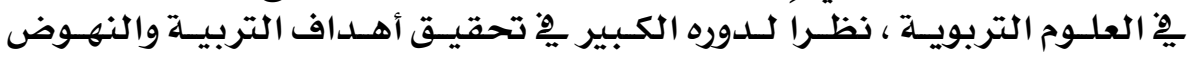

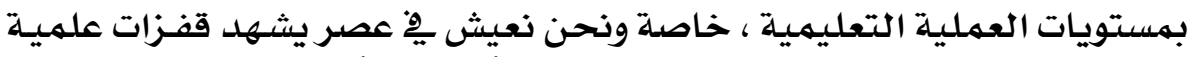

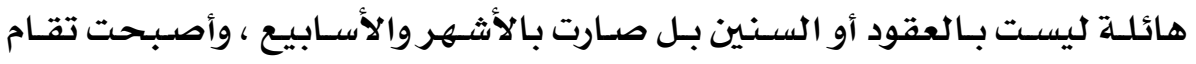

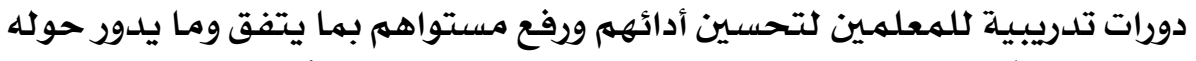

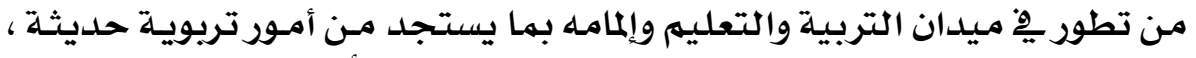

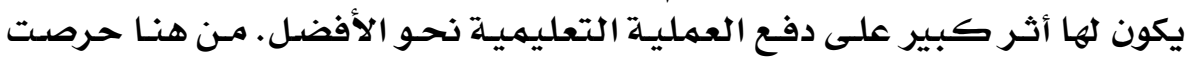

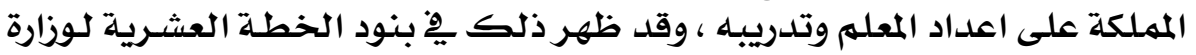

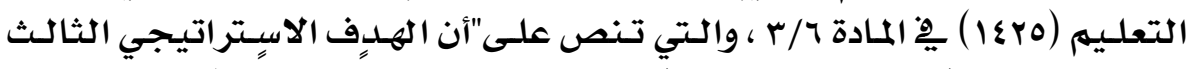

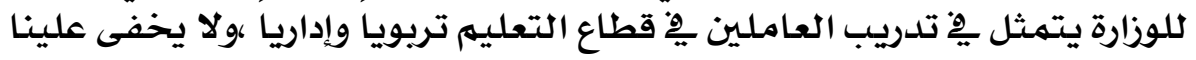

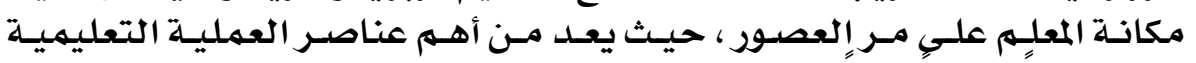

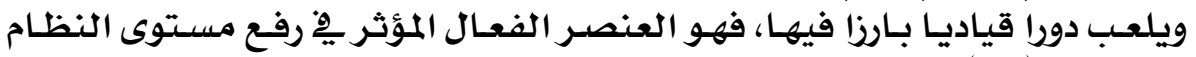
التعليهي" (rV ) (

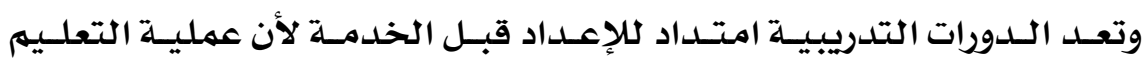

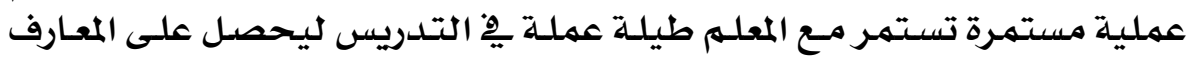

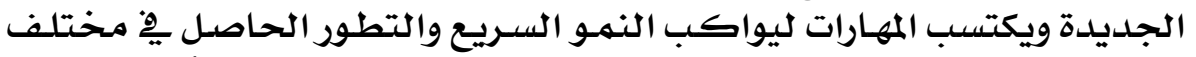

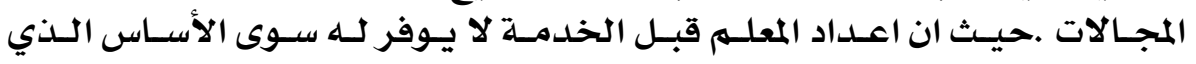

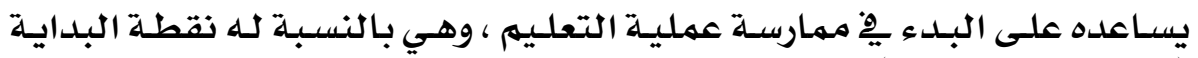

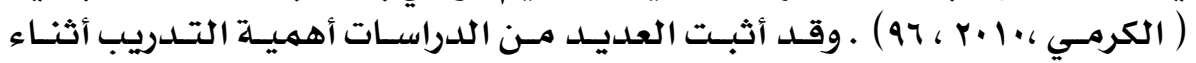

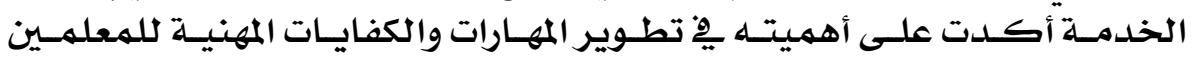

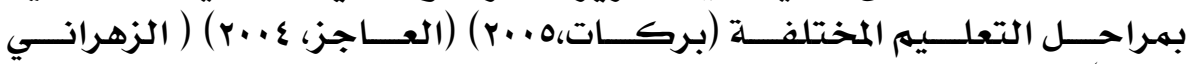

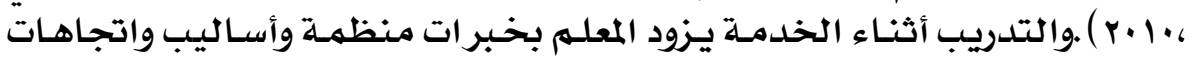

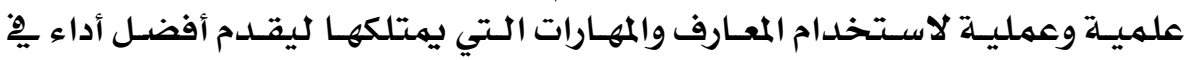

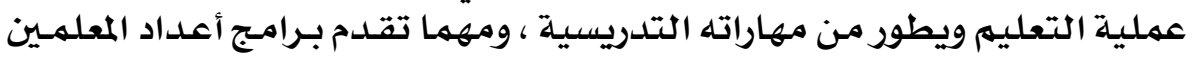

\section{rVq}




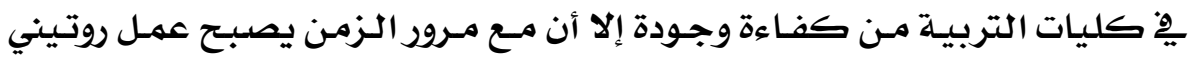

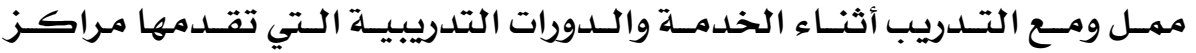

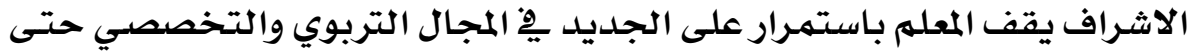

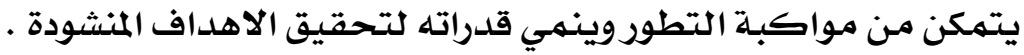

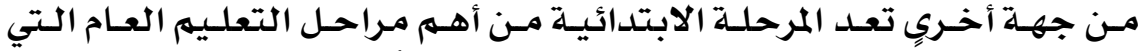

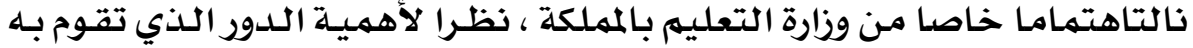

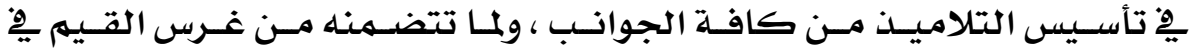

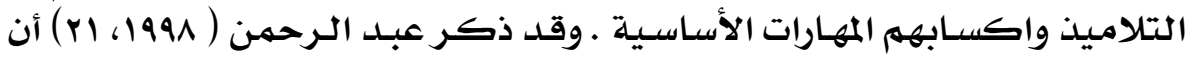

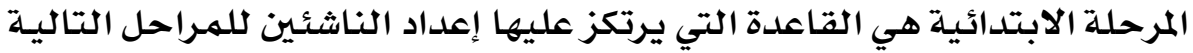

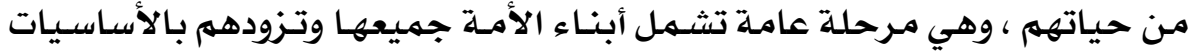

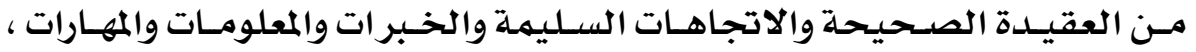

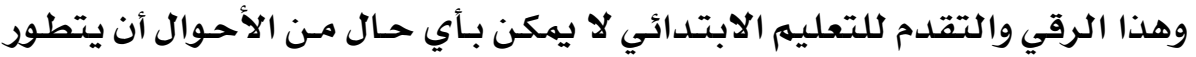

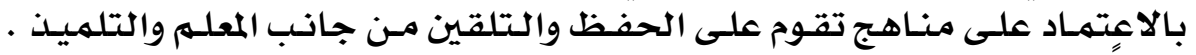

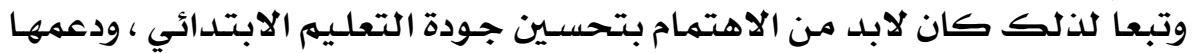

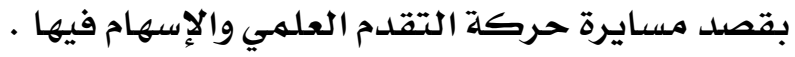

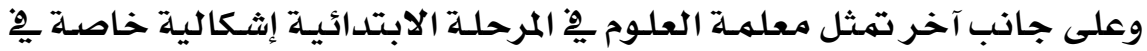

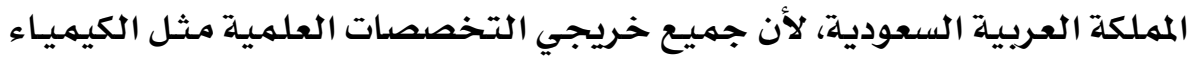

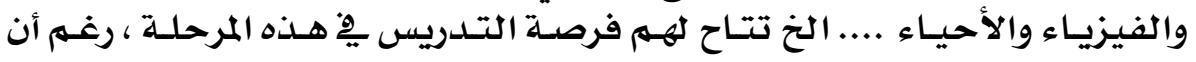

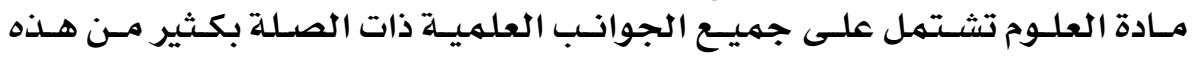

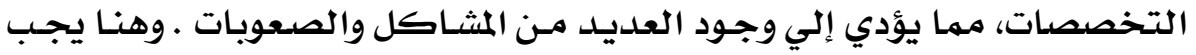

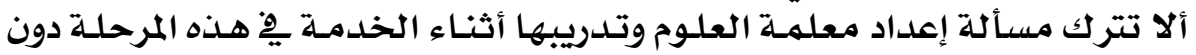

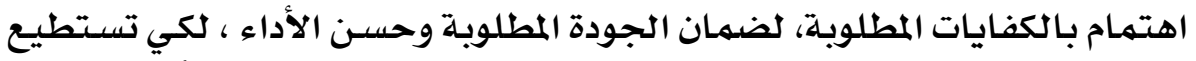

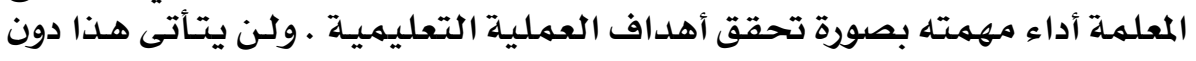

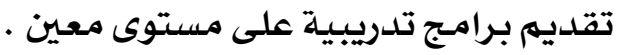

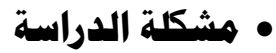

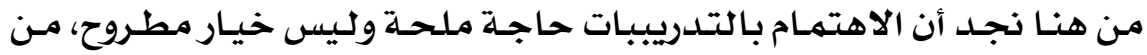

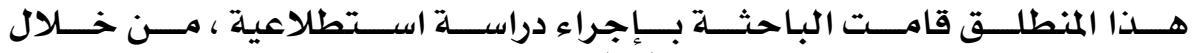

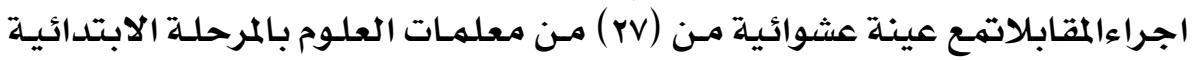

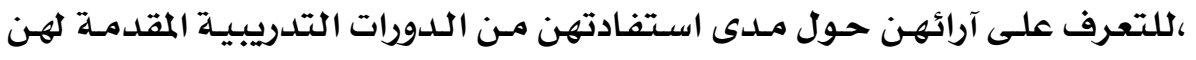

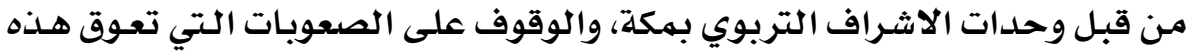

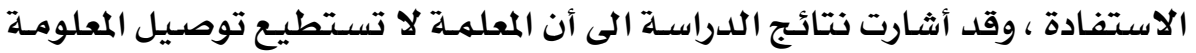

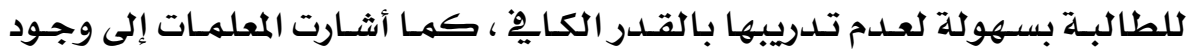

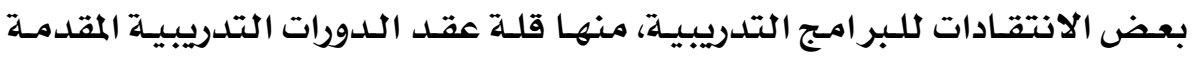

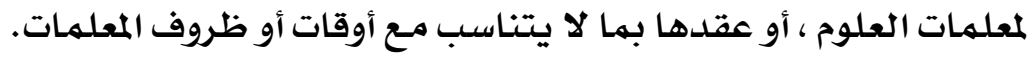

\section{rA.}




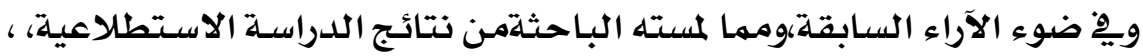

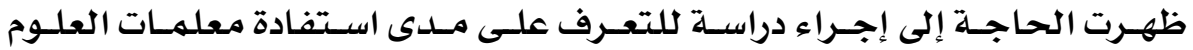

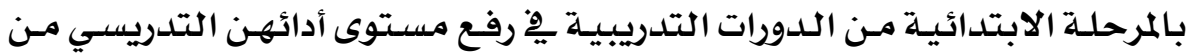

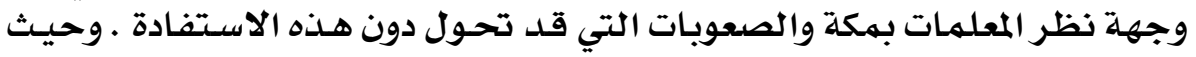

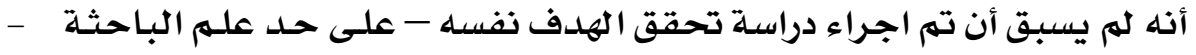

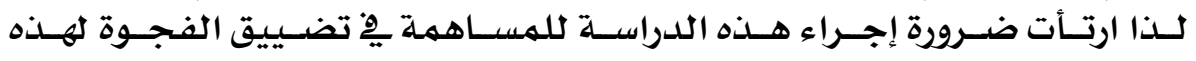

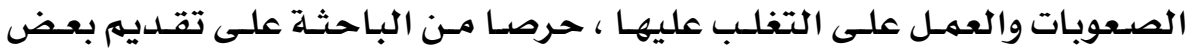

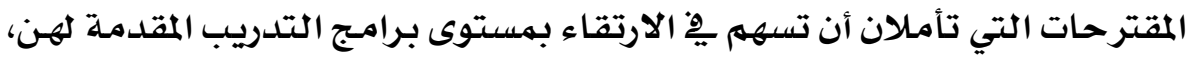

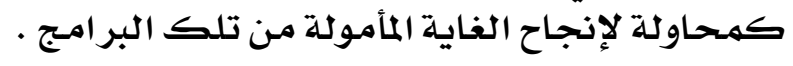

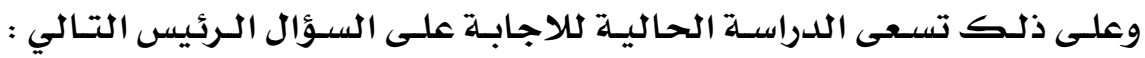

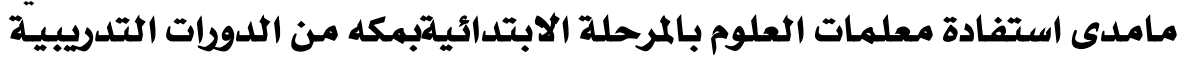
من وجهة نظر المعلمات

ولإجابة على السؤال الرئيسي يتطلب الإجابة على التساؤلات التابل التالية :

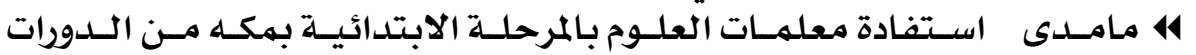

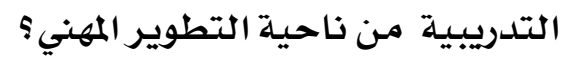

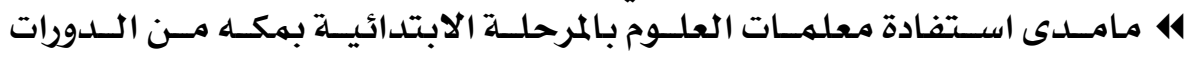

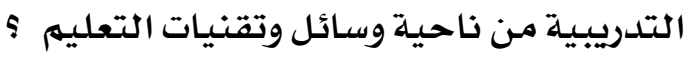

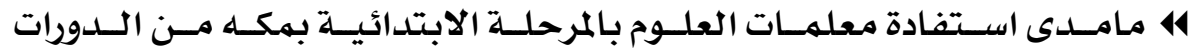

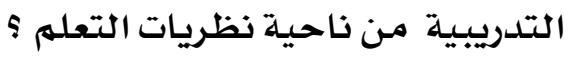

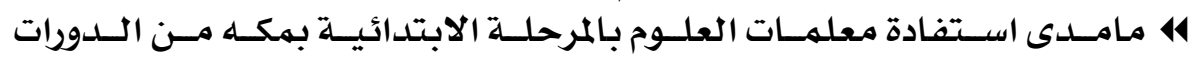

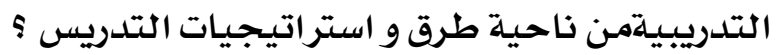

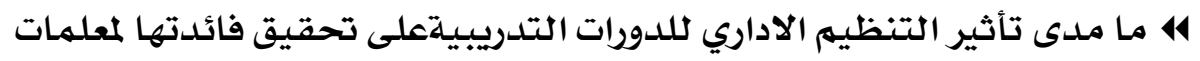

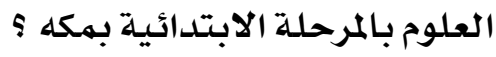

$$
\begin{aligned}
& \text { • أهداف الدراسة : } \\
& \text { هدفت الدراسة إلى : هدئ الدراسة : }
\end{aligned}
$$

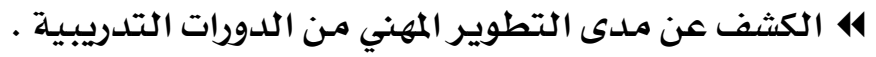

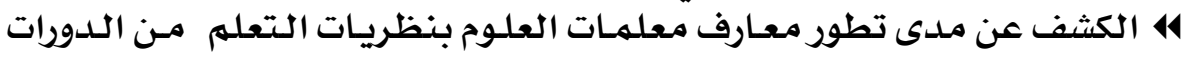

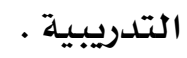

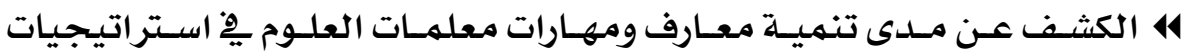

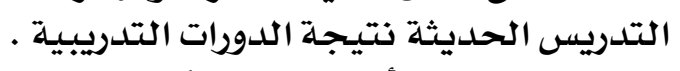

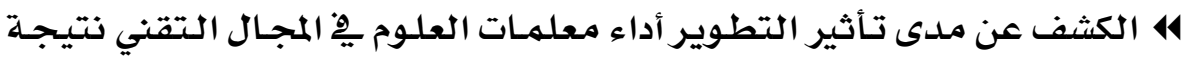

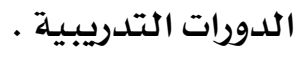

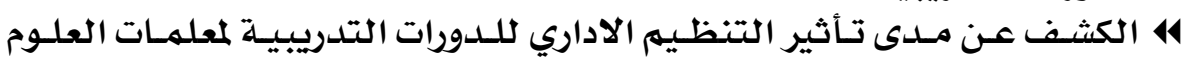

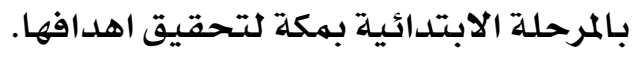

\section{rᄉ}




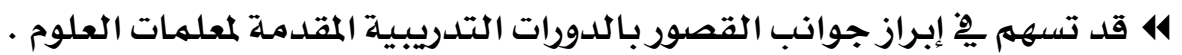

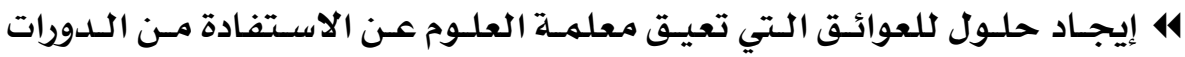

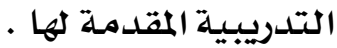

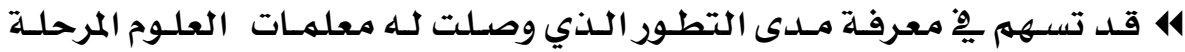

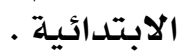

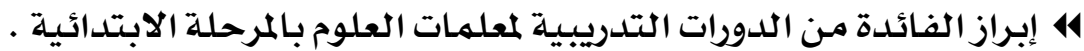

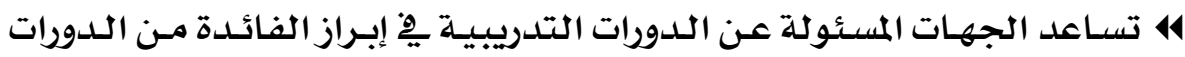

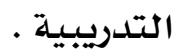

4 تفيد المسئولين بـبر امـج التـدريبلـحل مشكلـه عـزوف بعض معلمـات العلوم عن

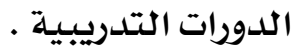

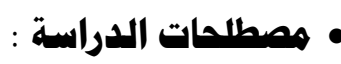

• مدى الاستفادة :

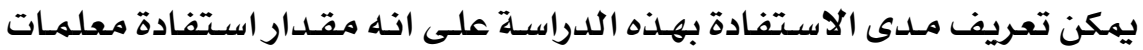

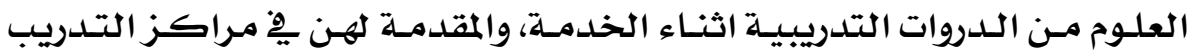

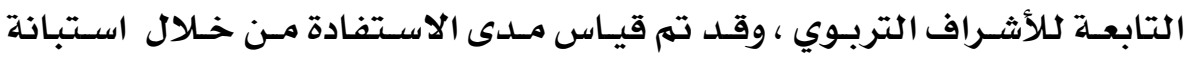

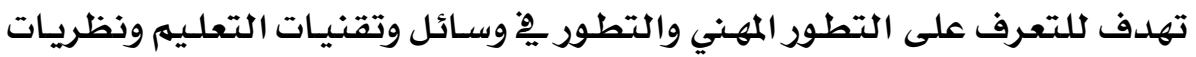

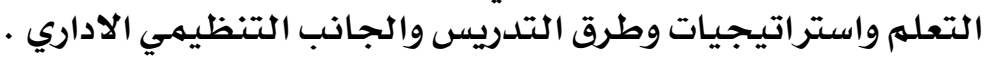

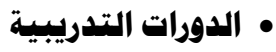

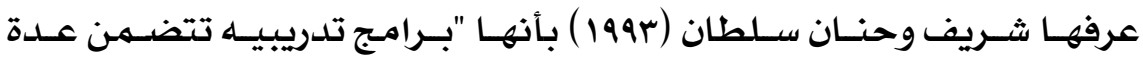

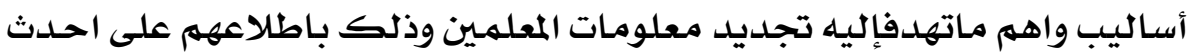

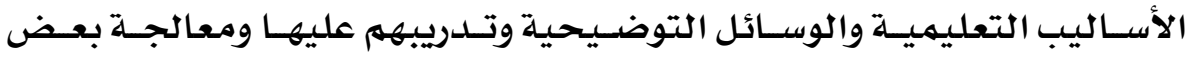

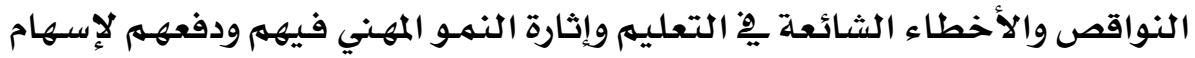

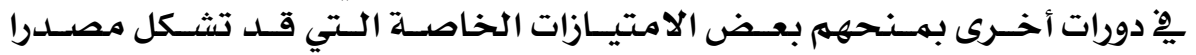

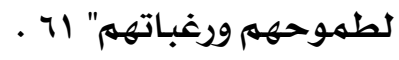

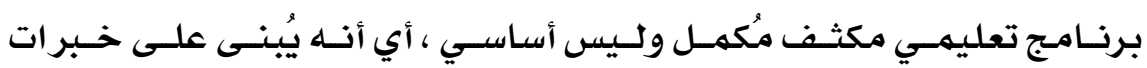

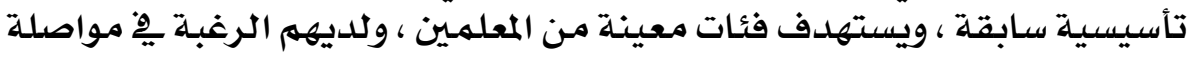

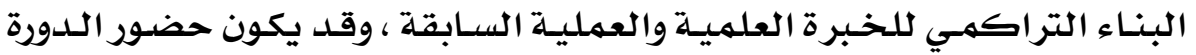

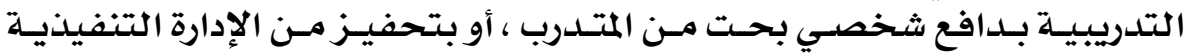

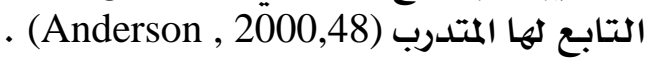

\section{• التدريب اثناء الخدهة}

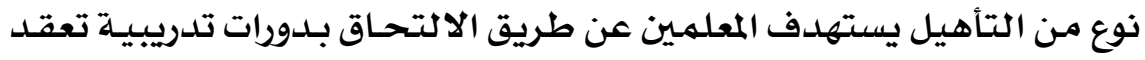

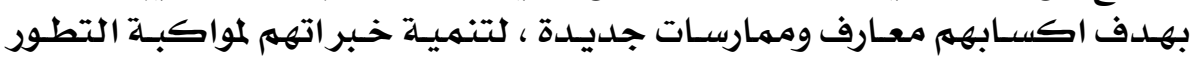

\section{rAY}




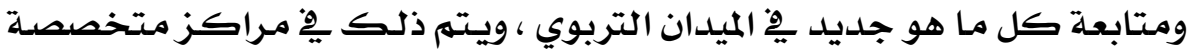

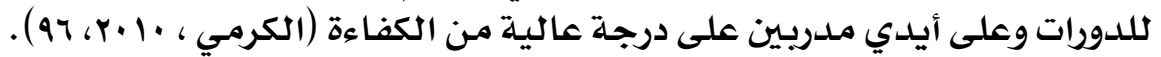

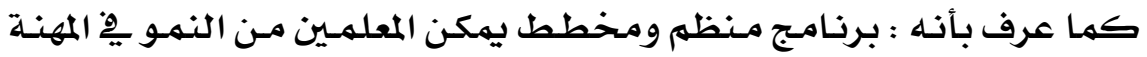

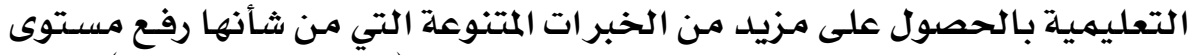

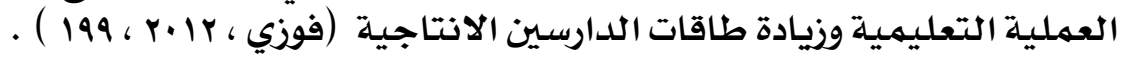

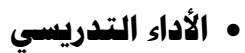

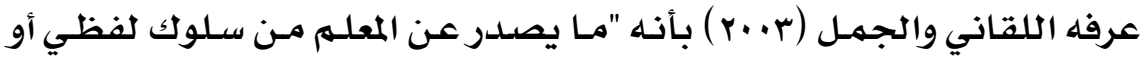

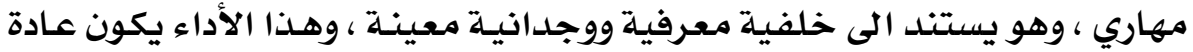

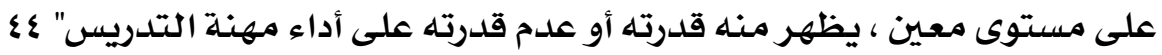

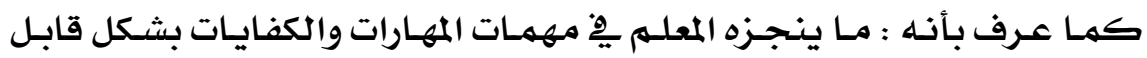

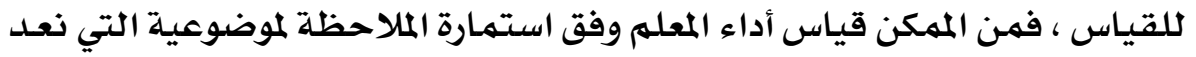

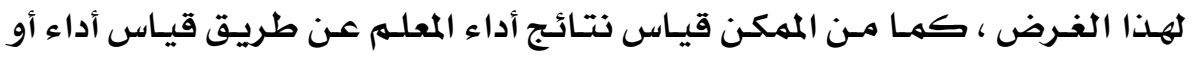

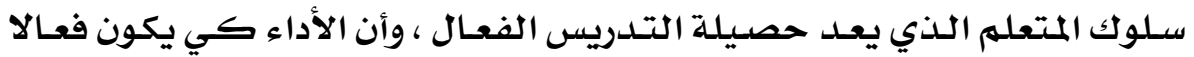

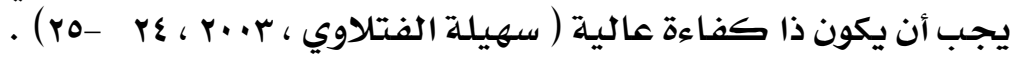

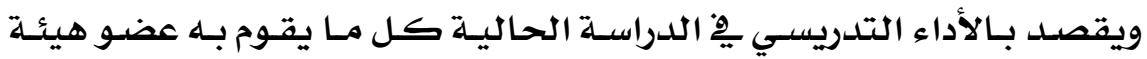

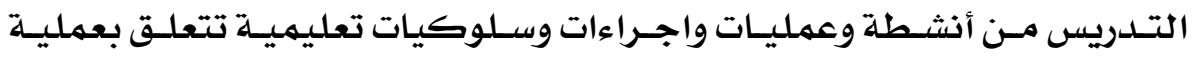
التدريس داخل الفصل أو خارجله . أنشيسل

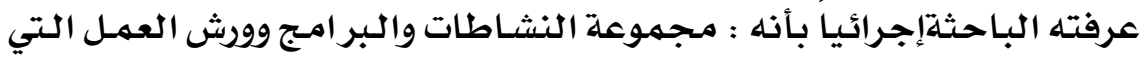

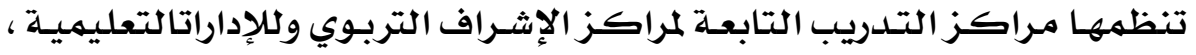

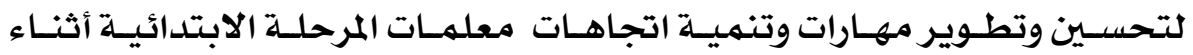
الخدمة .

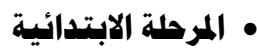

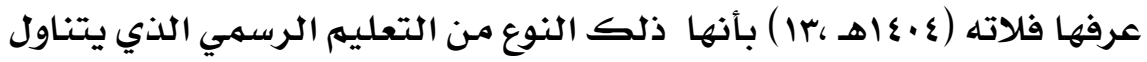

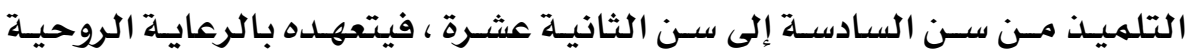

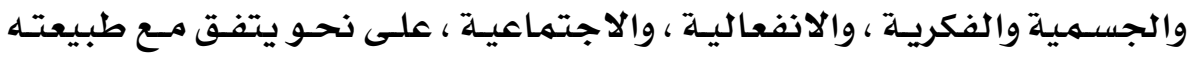

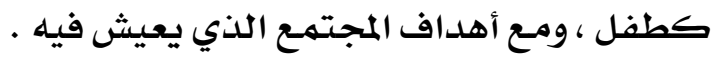

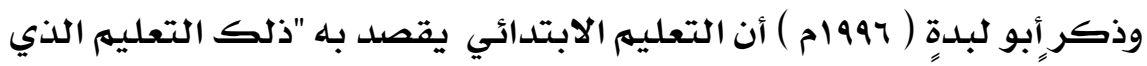

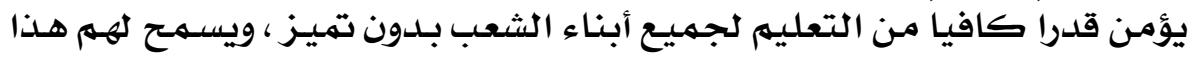

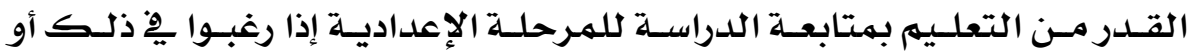

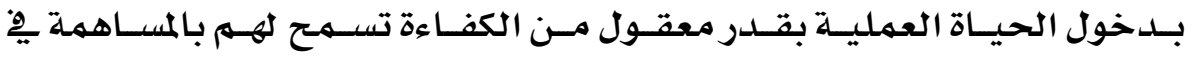

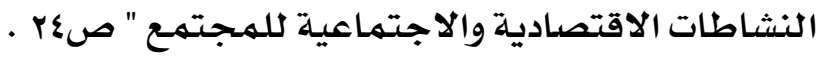

\section{$\mathrm{rAY}$}




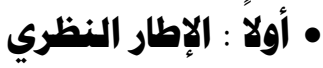

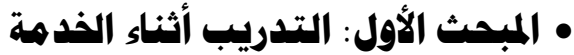

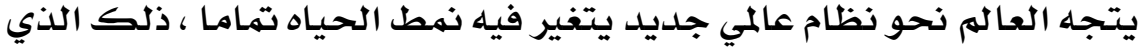

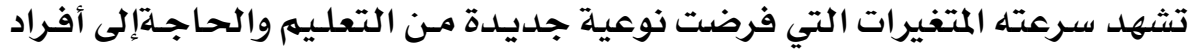

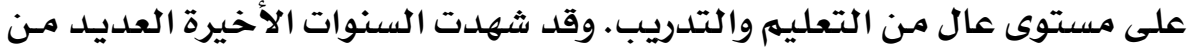

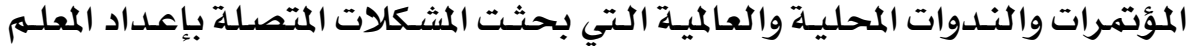

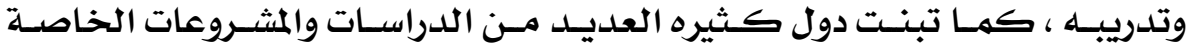

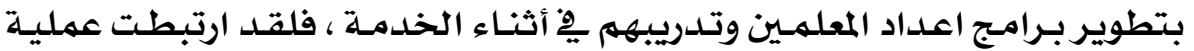

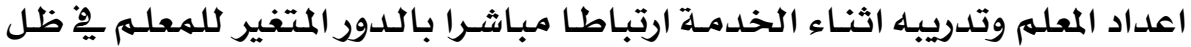

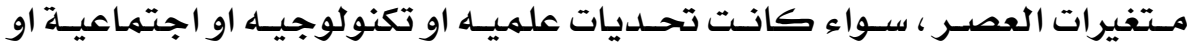

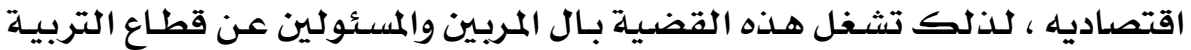

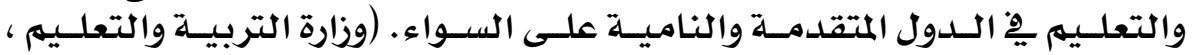
. ( $19 \wedge 1$

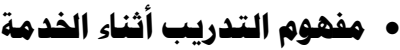

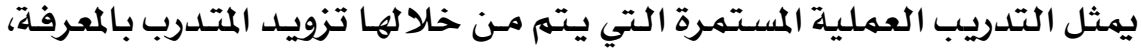

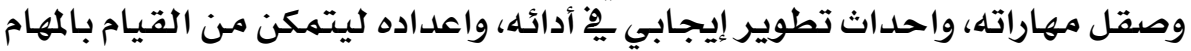

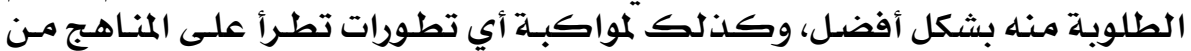

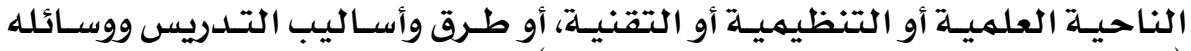

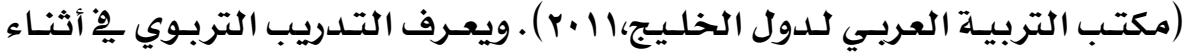

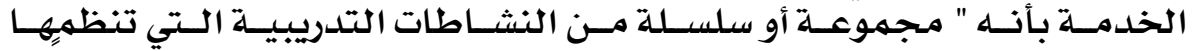

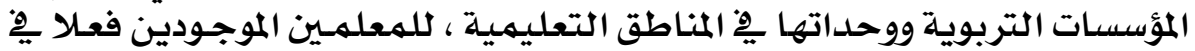

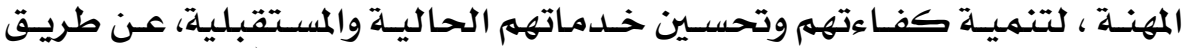

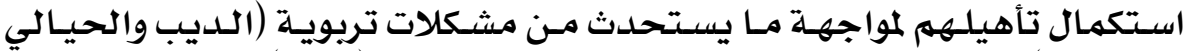

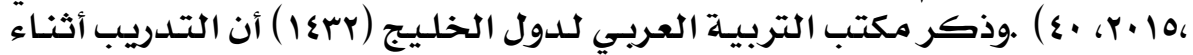

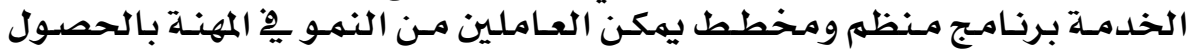

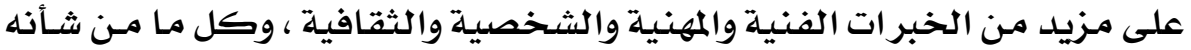

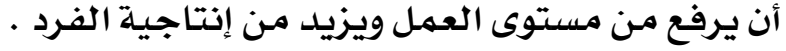

ويركز التدريب التربوي أثناء الخدمـةعلى المفاهيهم الثلاثة التالية:

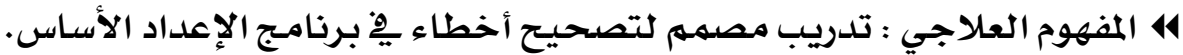

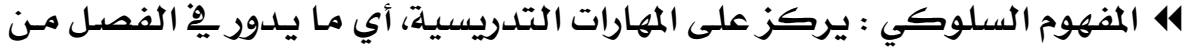

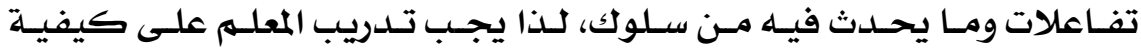

$$
\text { تحليل الموقف التدريسي. }
$$

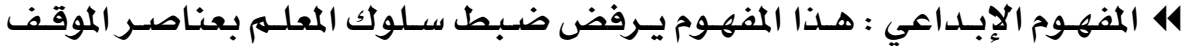

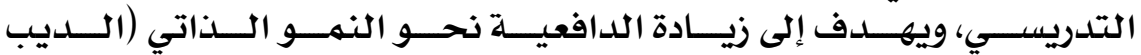

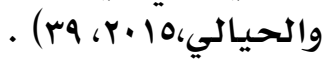

\section{rA}




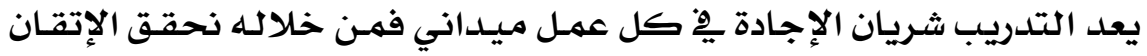

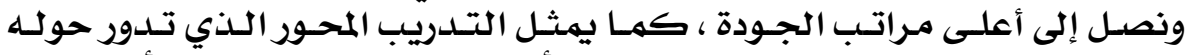

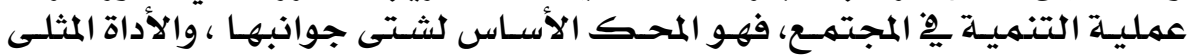

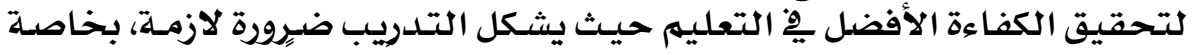

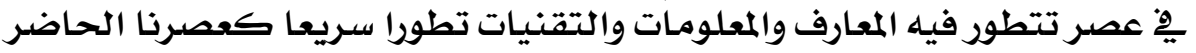

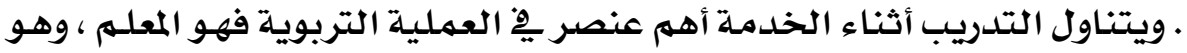

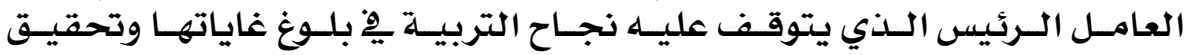

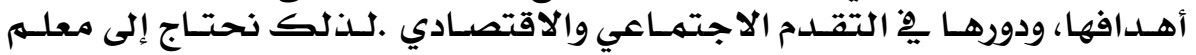

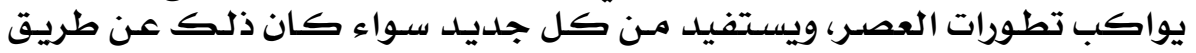

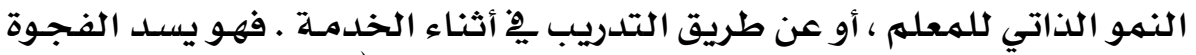

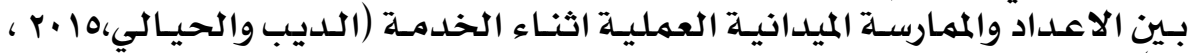
. (or

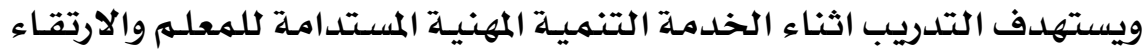

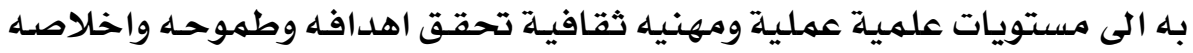

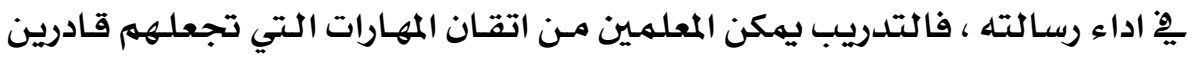

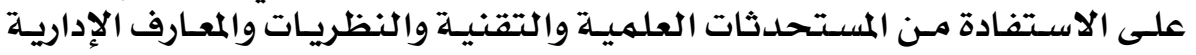

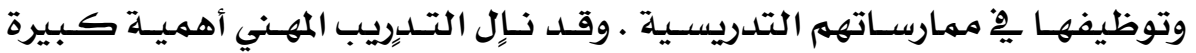

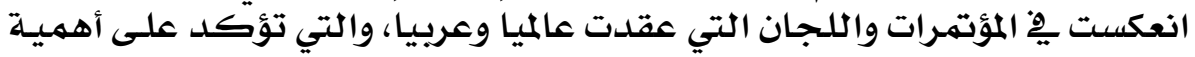

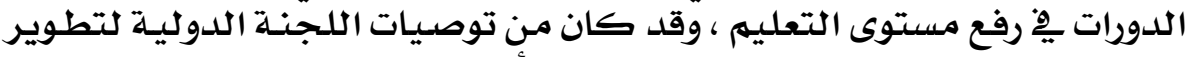

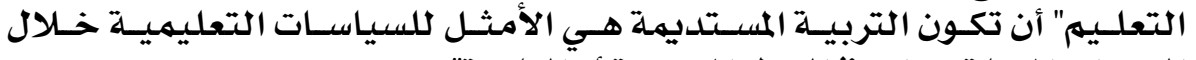

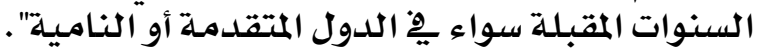

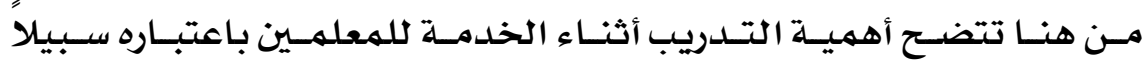

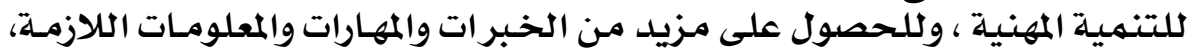

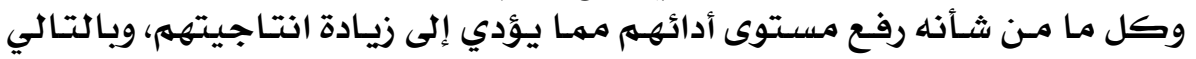

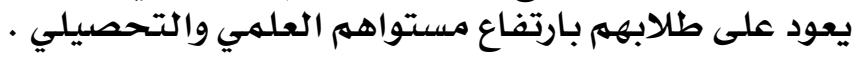

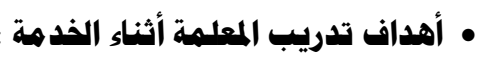

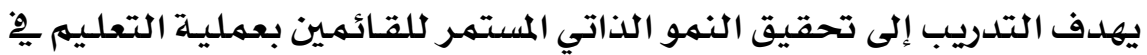

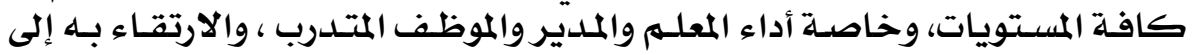

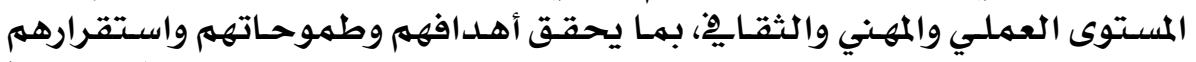

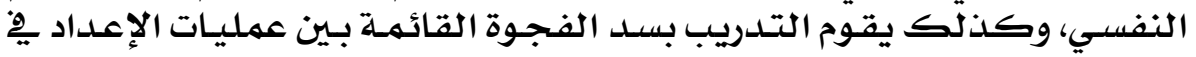

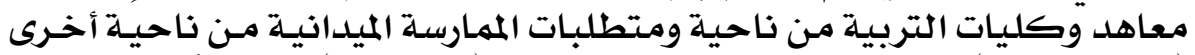

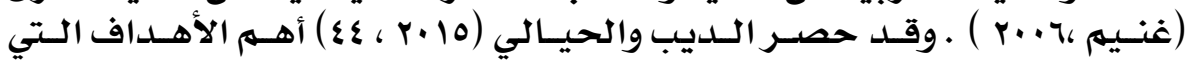

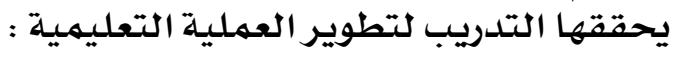

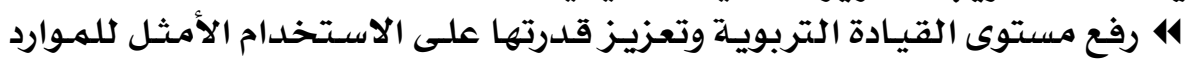

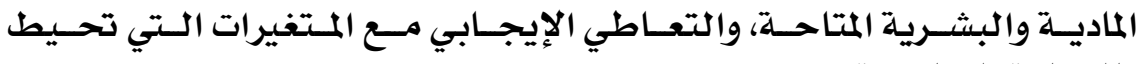
بالعملية التعليمية.

\section{rAO}


العكد الخاهس والسبعلن .. يوليو .. 17•؟م

414 تطوير الأداء المالي والإداري للمؤسسة التعليميـة.

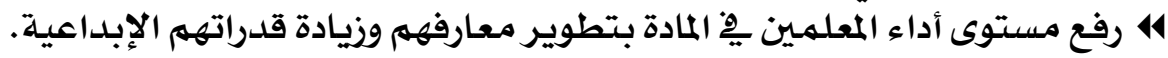

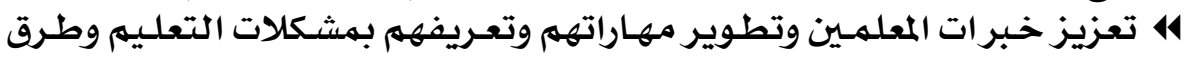

علاجها.

4 تبصير المعلهم بالطرق المناسبة لمساعدته على أداء عملـه بطريقـة جيـدة وبجهـد

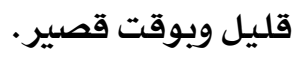

4 معالجة أوجه القصور لدير، لدى المعلمـين الغير مؤهلين تربوياً.

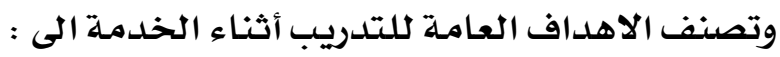

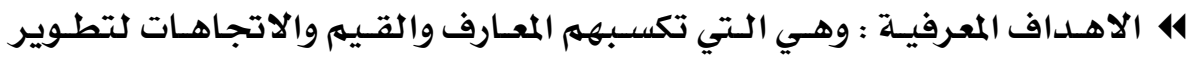

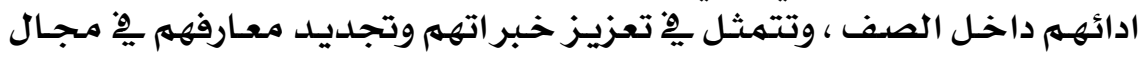

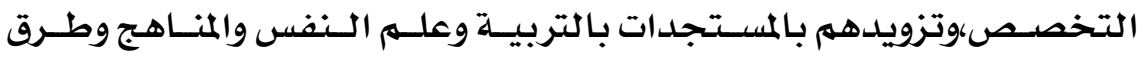

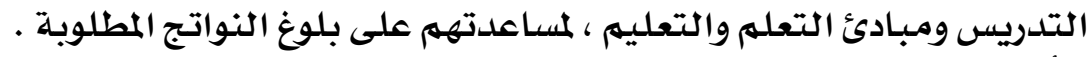

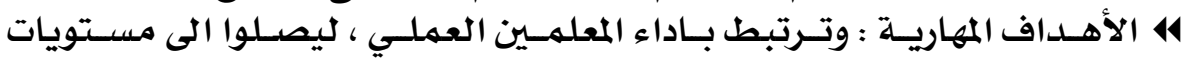

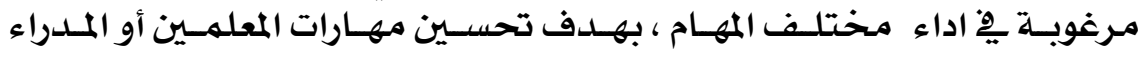

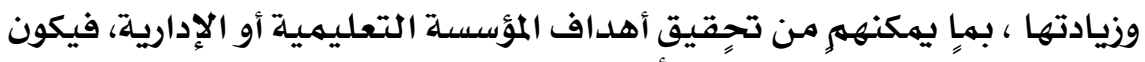

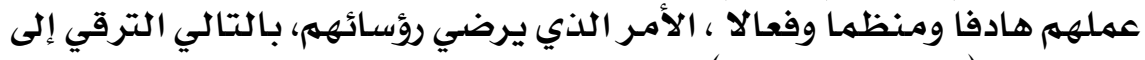

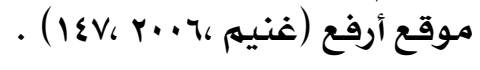

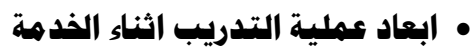

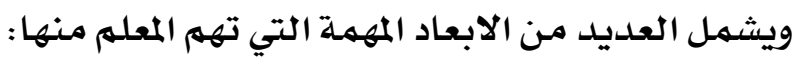

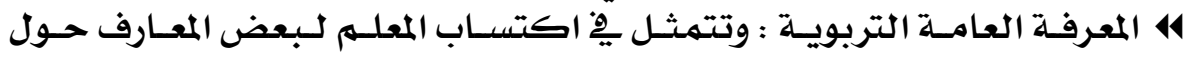

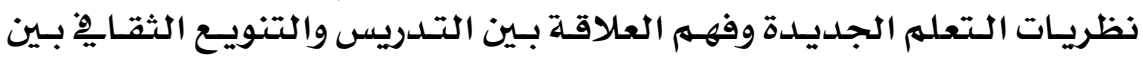

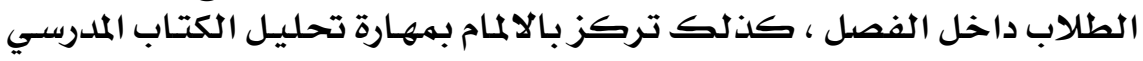

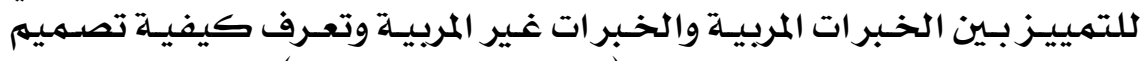

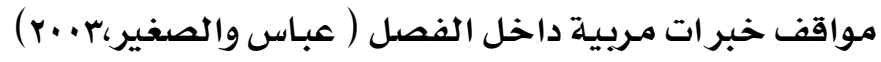

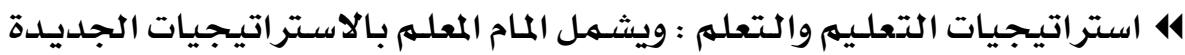

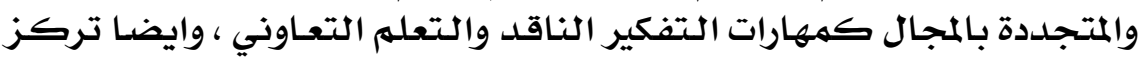

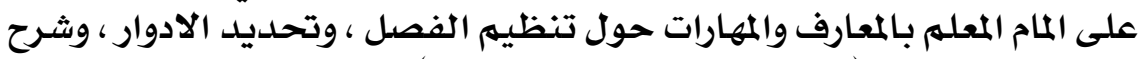

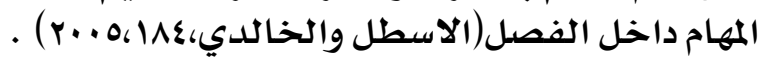

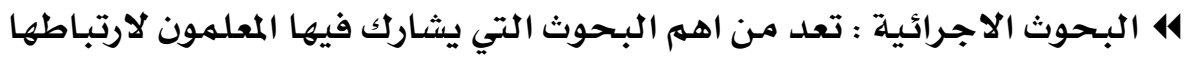

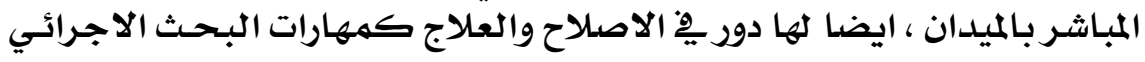

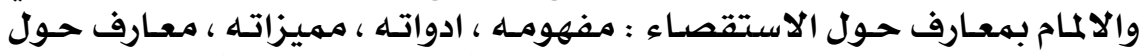

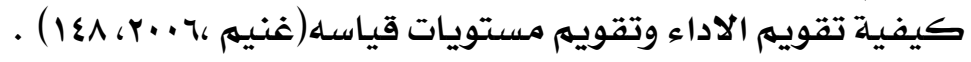

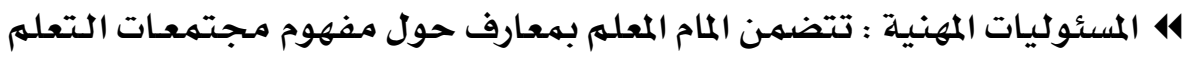

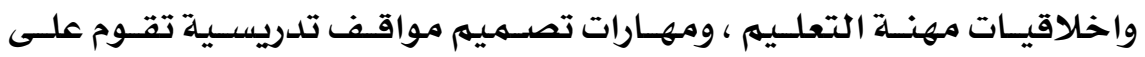

\section{พ^}




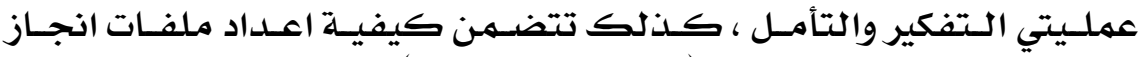

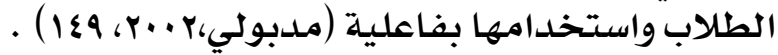

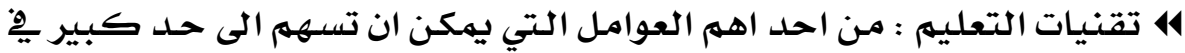

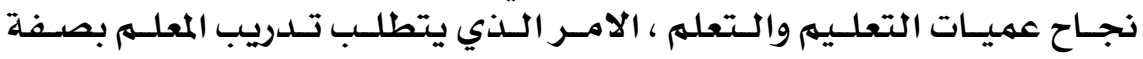

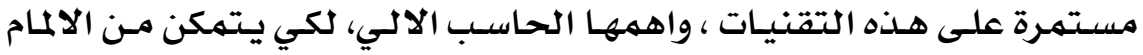

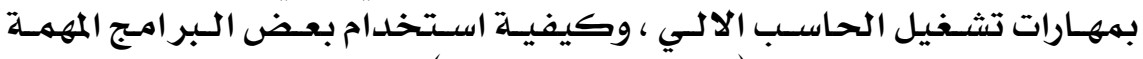

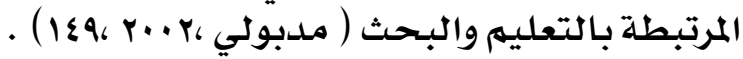

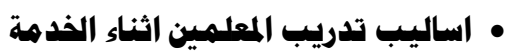

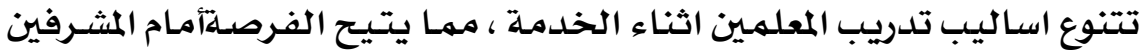

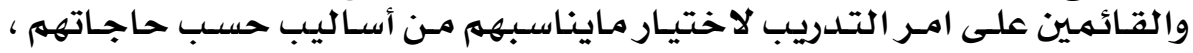

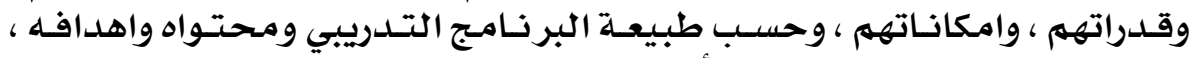

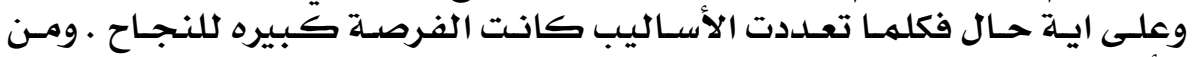

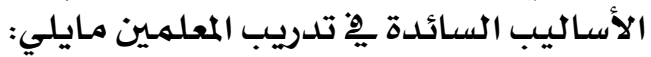

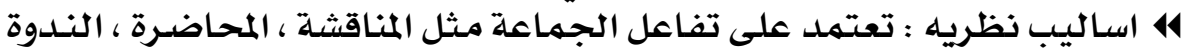

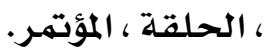

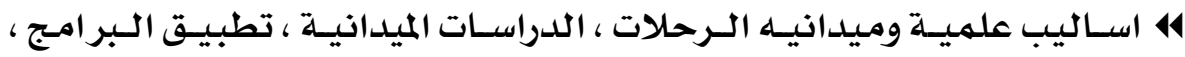

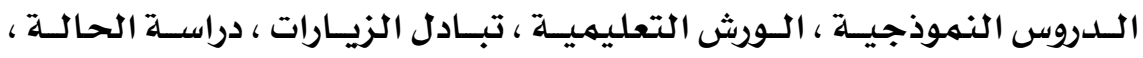

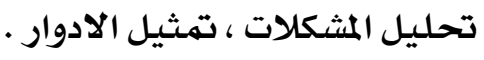

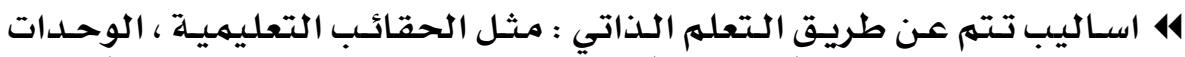

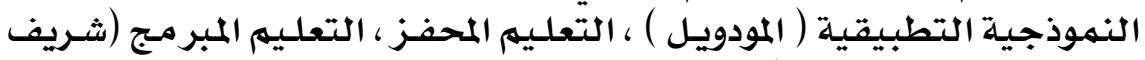

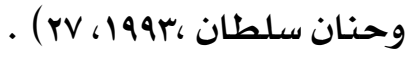

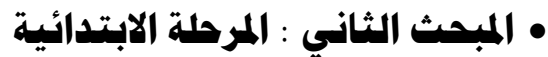

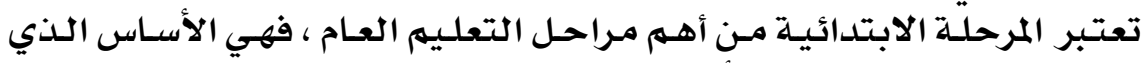

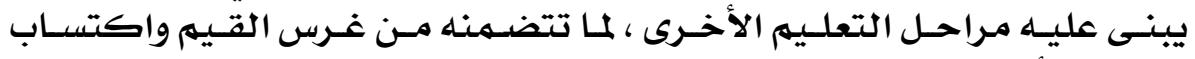

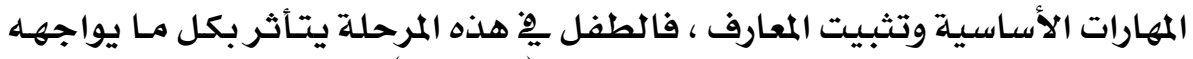

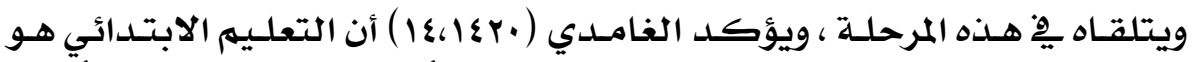

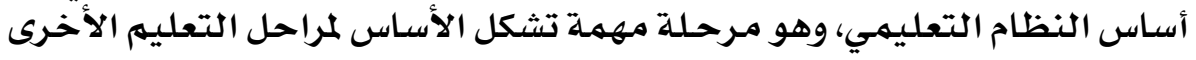

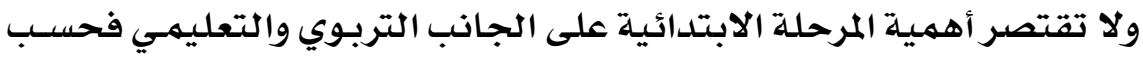

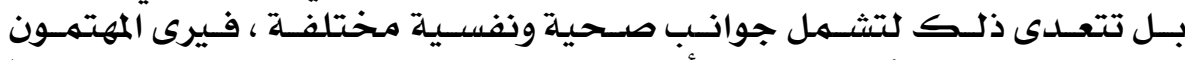

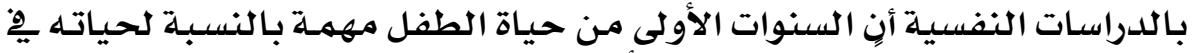

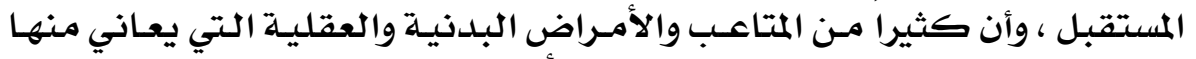

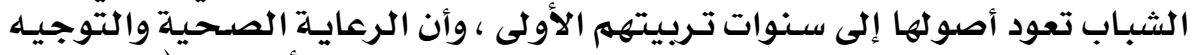

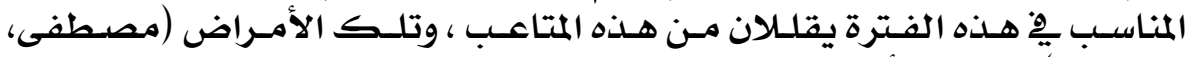

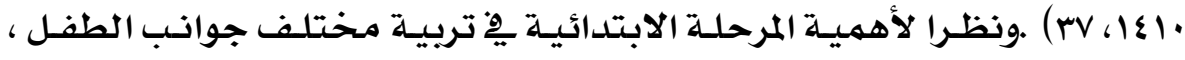

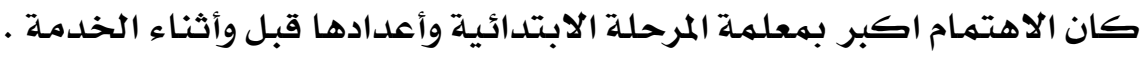

\section{rAV}




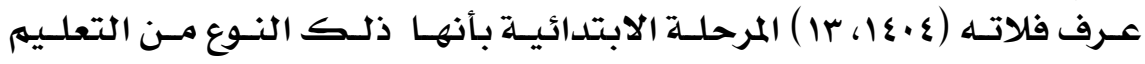

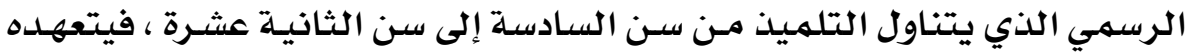

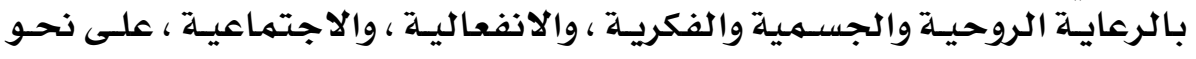

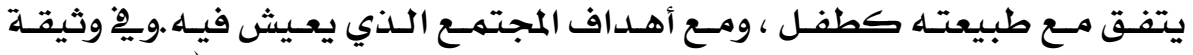

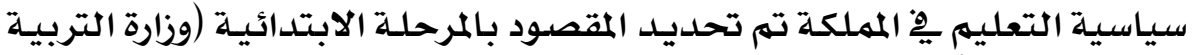

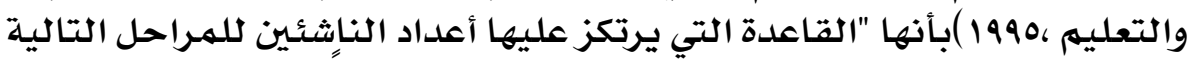

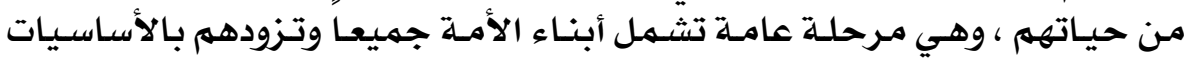

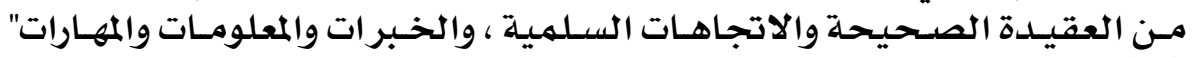

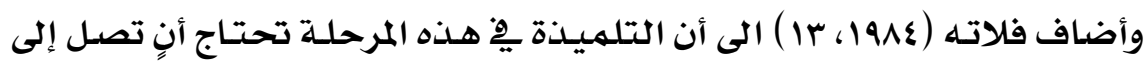

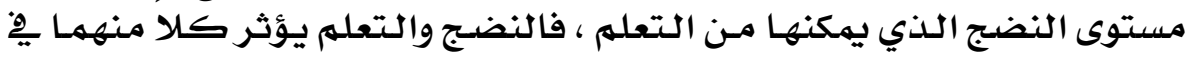

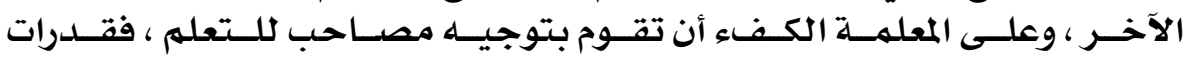

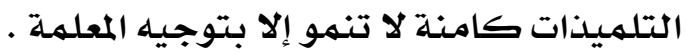

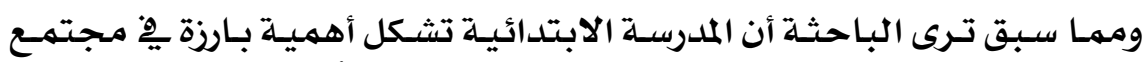

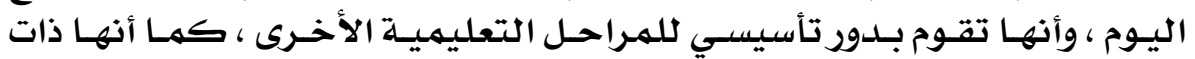

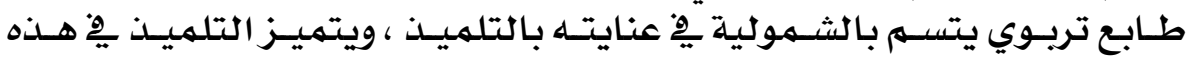

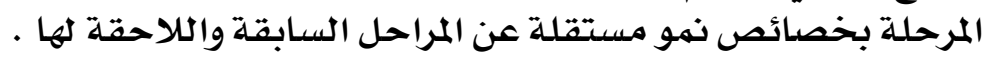

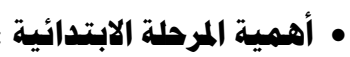

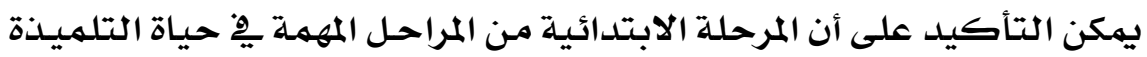

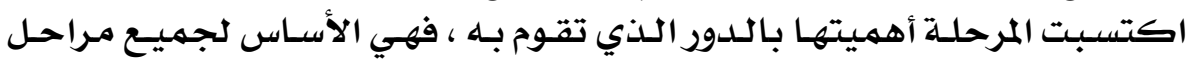

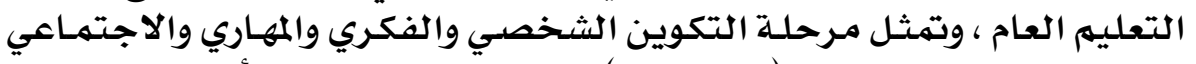

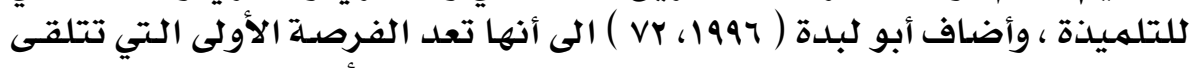

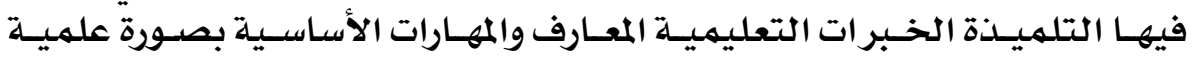

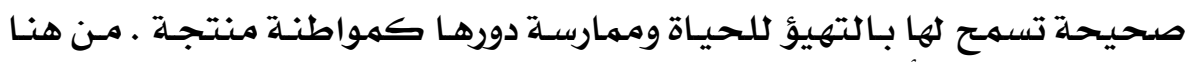

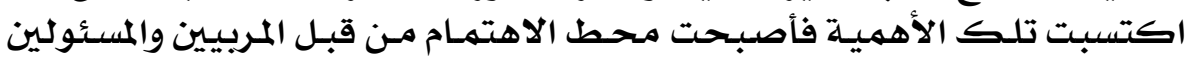

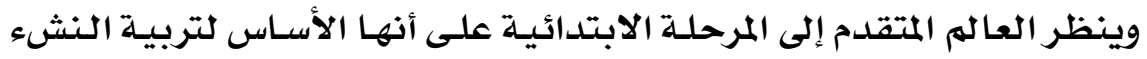

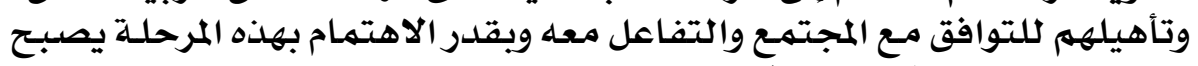

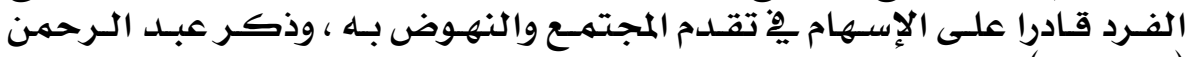

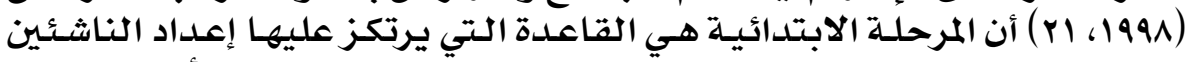

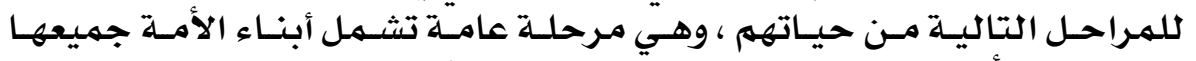

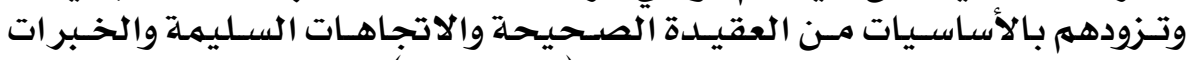

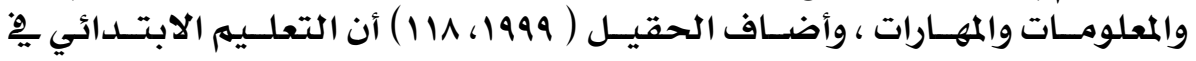

\section{$\wedge \wedge$}




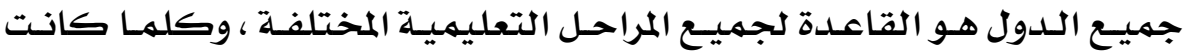

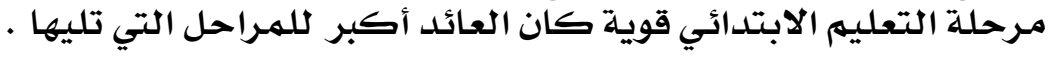

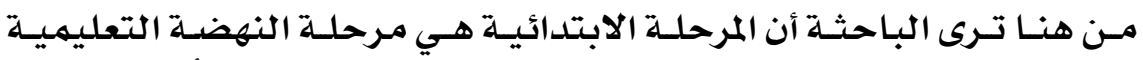

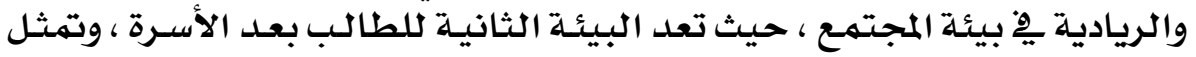

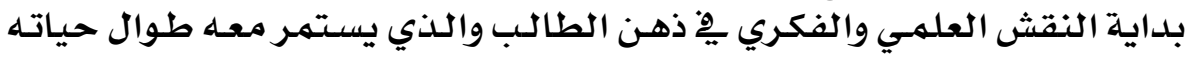

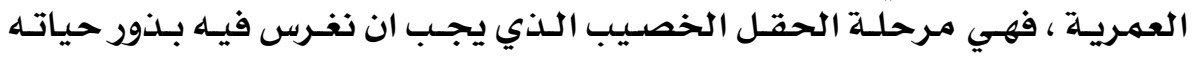

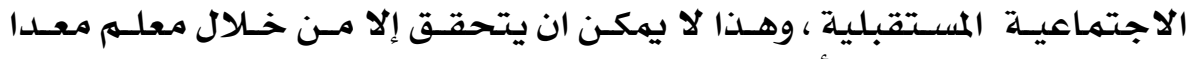

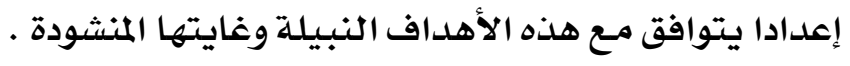

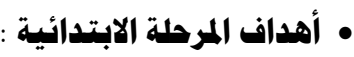

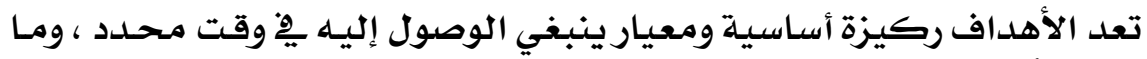

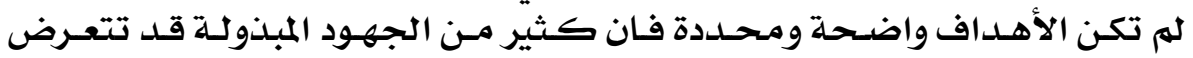

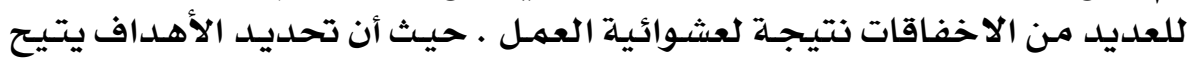

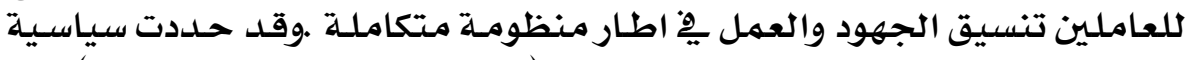

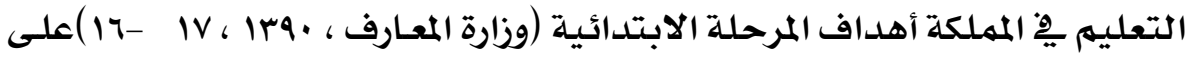

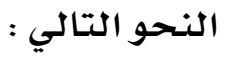

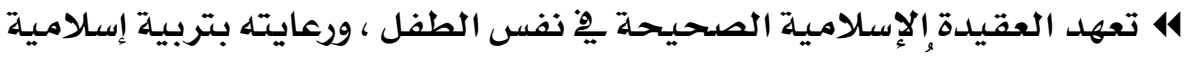

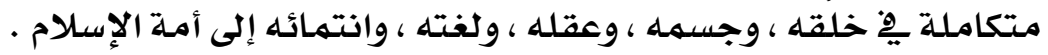

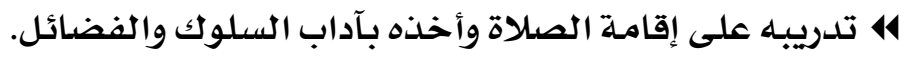

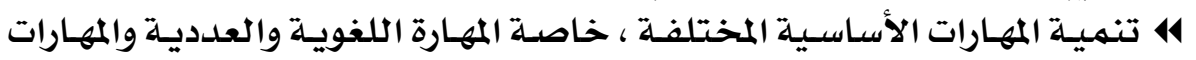

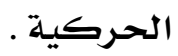

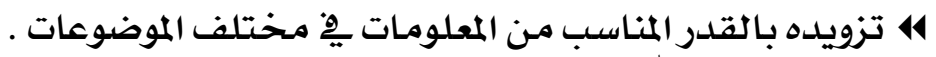

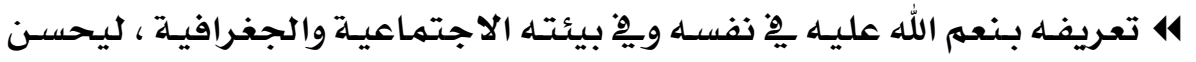

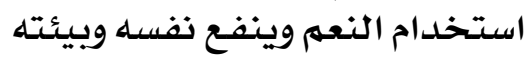

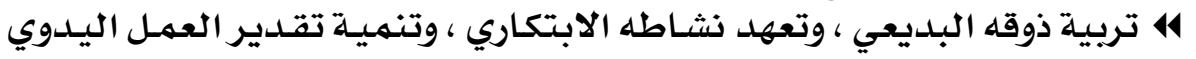
لديه . لدرية دوت

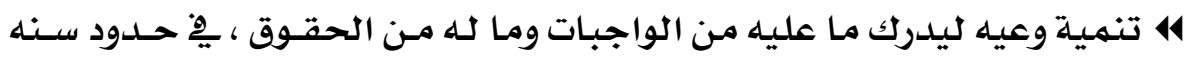

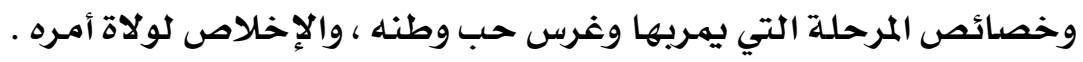

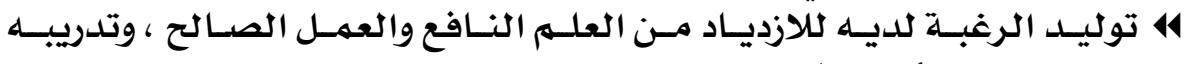

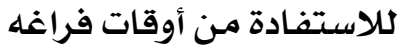

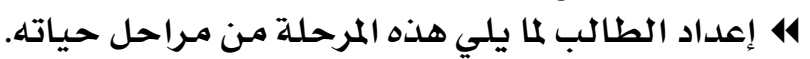

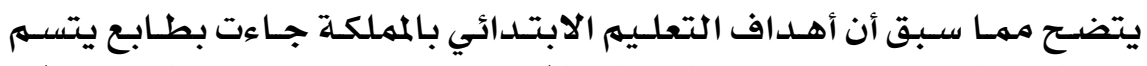

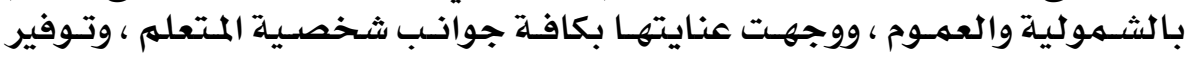

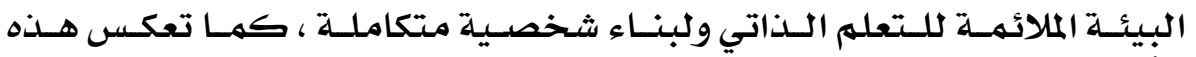

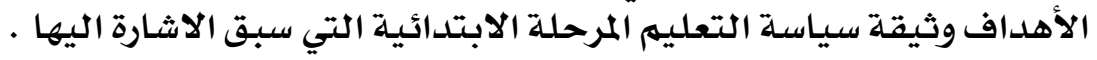

\section{พ^q}




\section{• خصائص النهمو للهرحلة الابتدائية :}

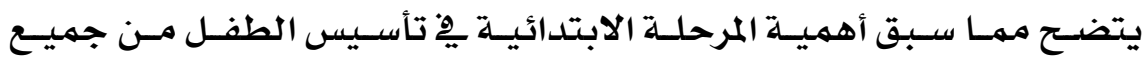

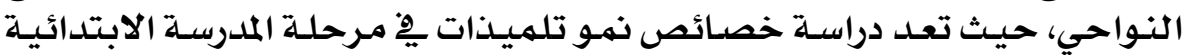

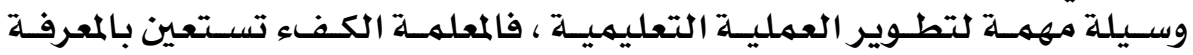

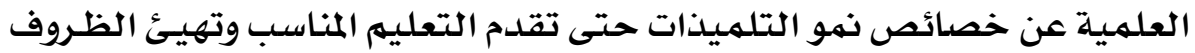

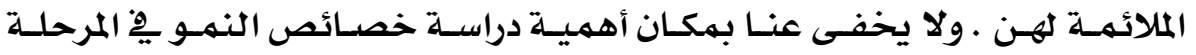

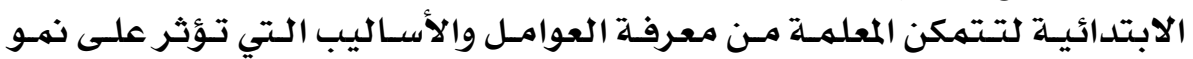

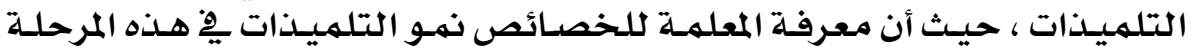

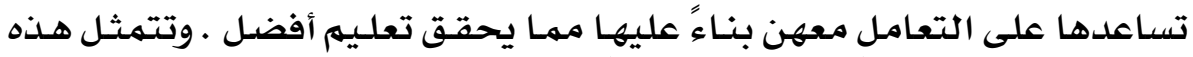

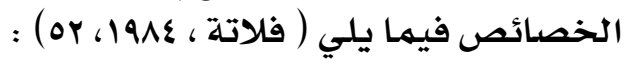

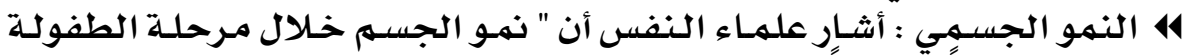

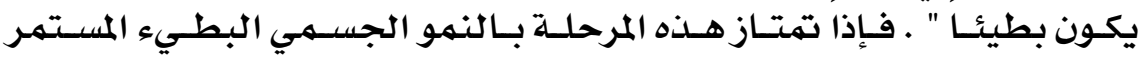

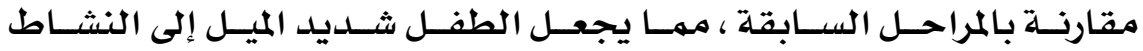

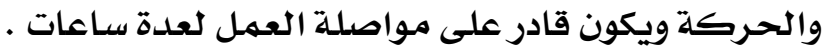

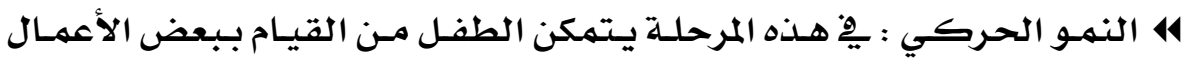

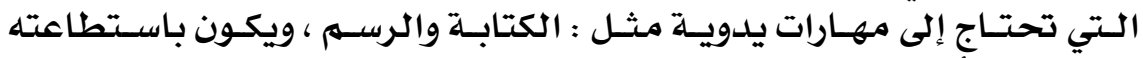

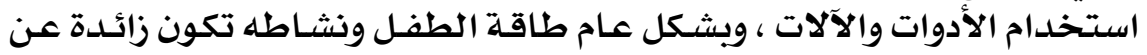

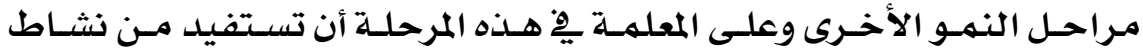

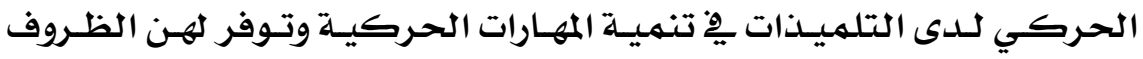

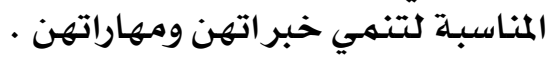

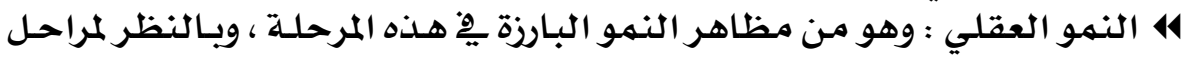

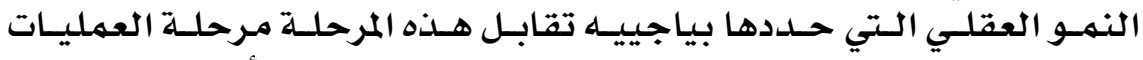

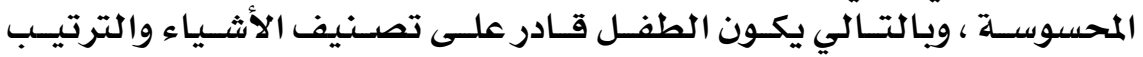

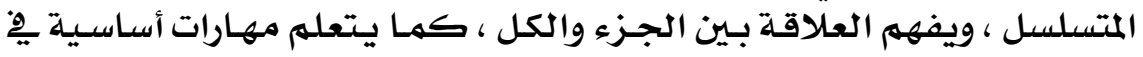

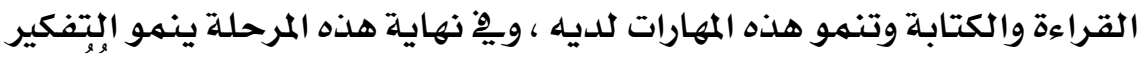

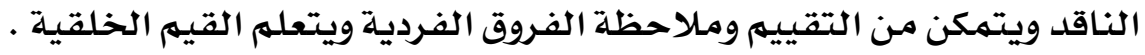

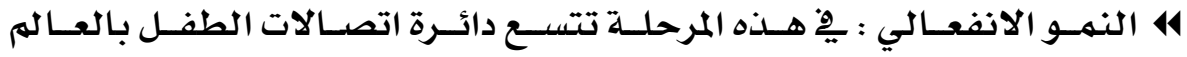

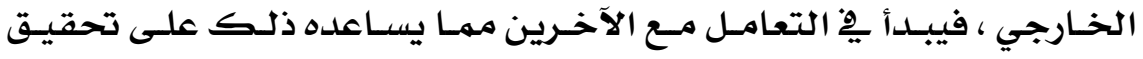

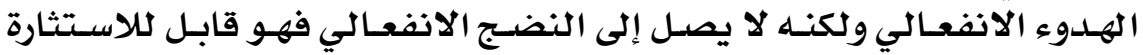

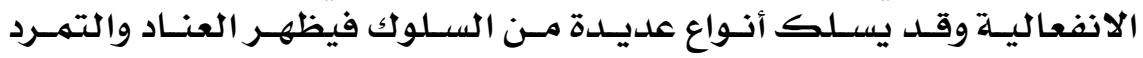
والغيرة . الانفعال

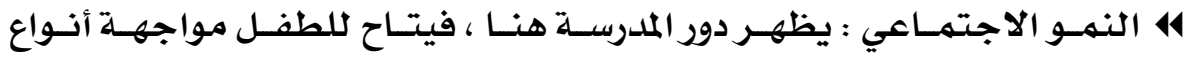

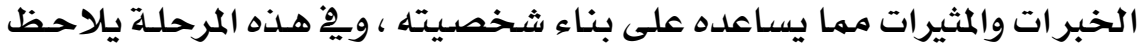

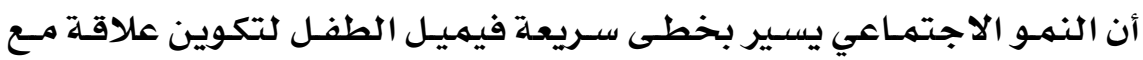

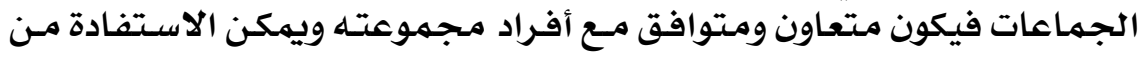

\section{rq.}


العقد الخاهس والسبعهن .. بيوليه .. 17•آم .

هذا الميل ِِّ تطبيق استراتجيه التعلهم التعاوني الذي يهدف إلى أثارة المنافسـة

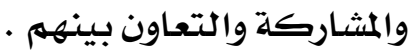

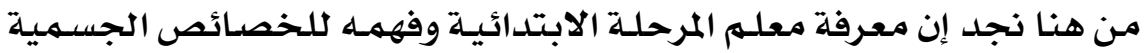

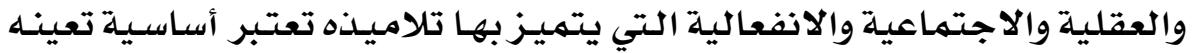

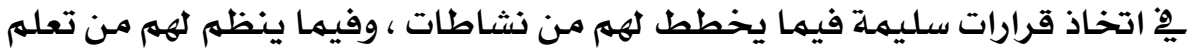

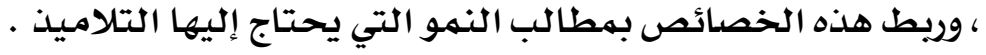

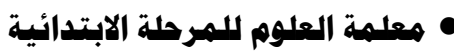

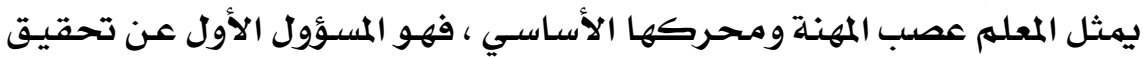

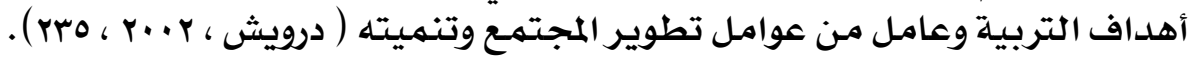

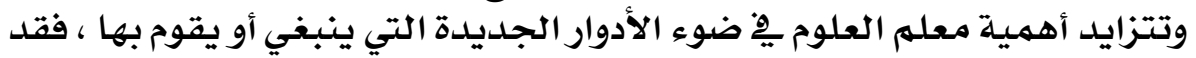

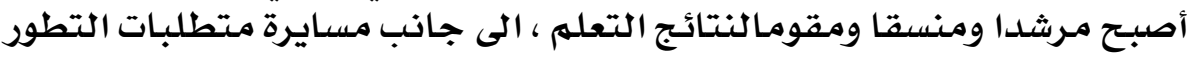

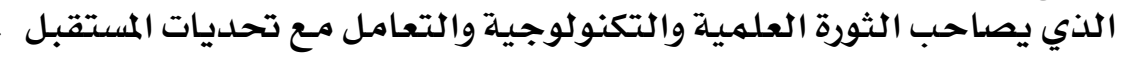

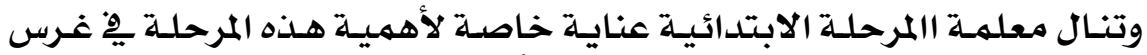

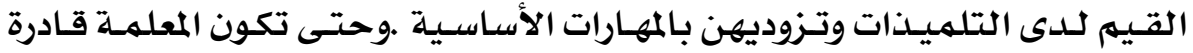

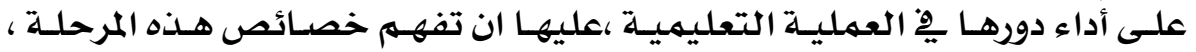

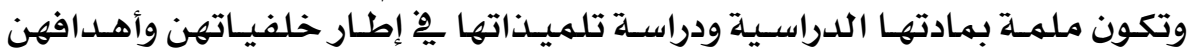

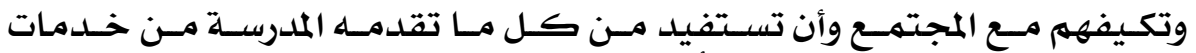

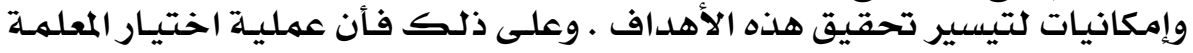

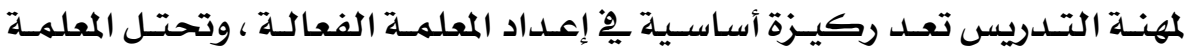

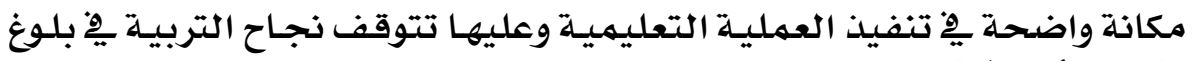

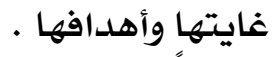
• ثانيا : الدراسات وآهداف السابقة :

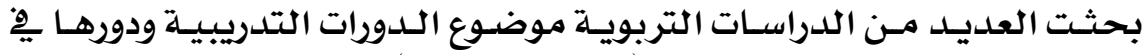

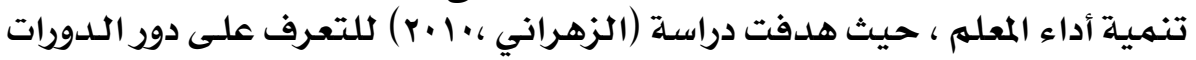

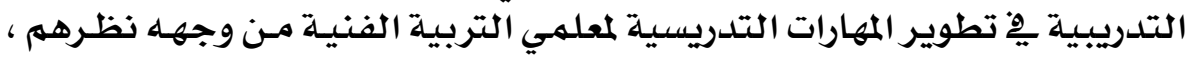

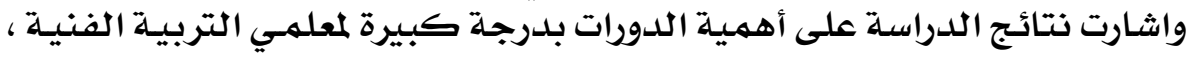

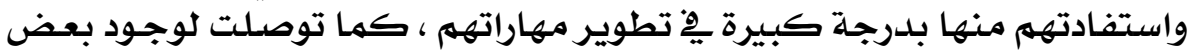

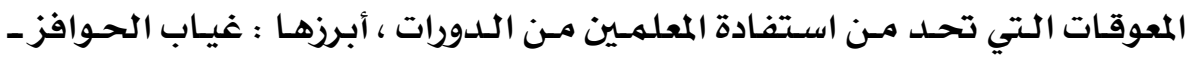

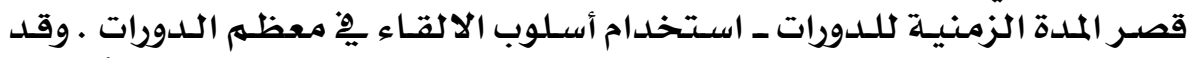

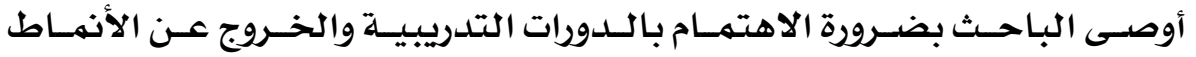

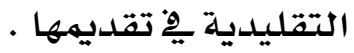

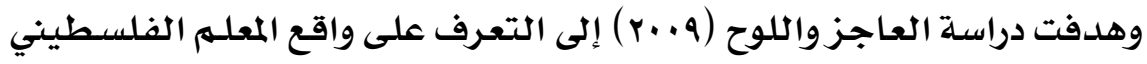

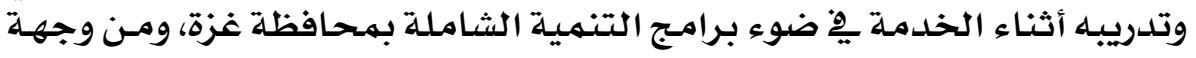

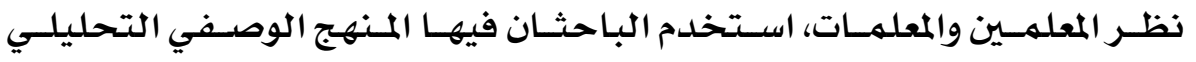

\section{Yq}




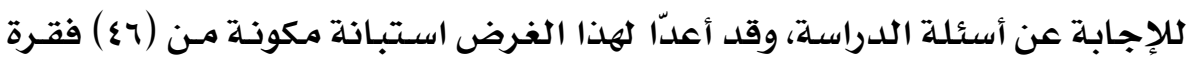

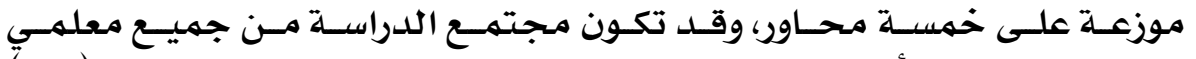

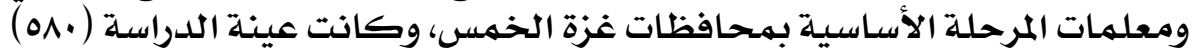

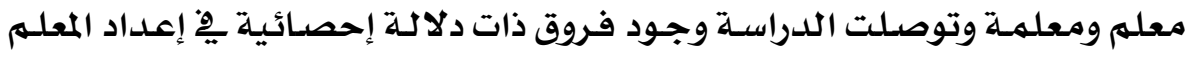

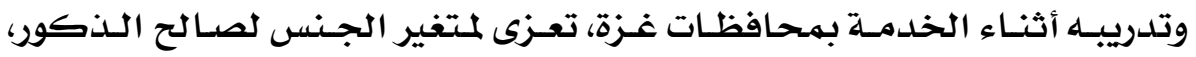

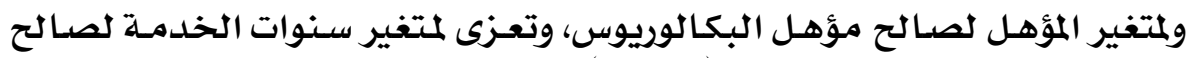

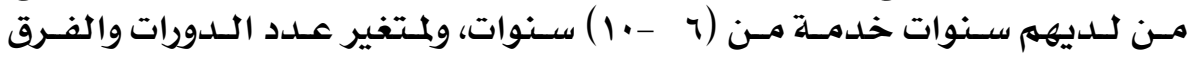

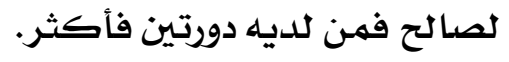

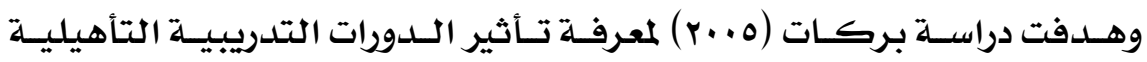

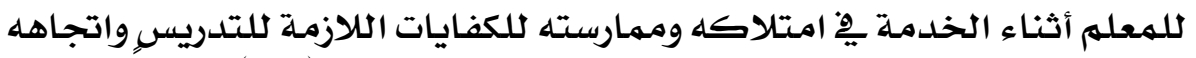

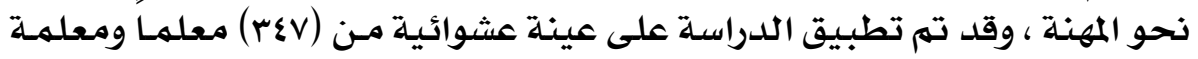

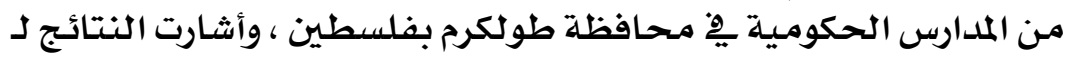

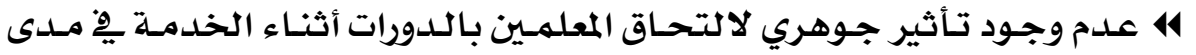

$$
\text { امتالامهم للكفايات التدريسية تهوية. }
$$

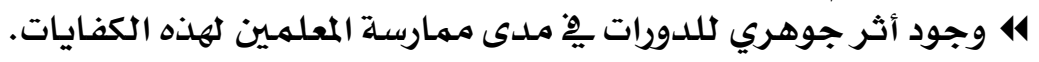

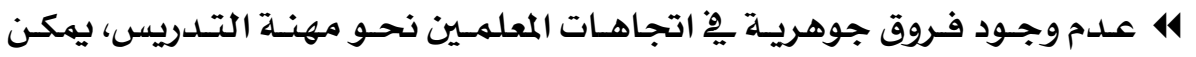

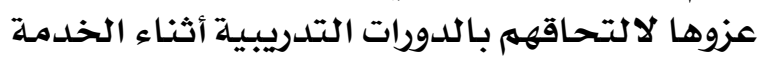

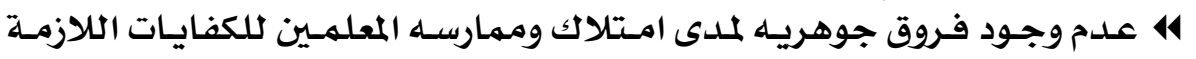

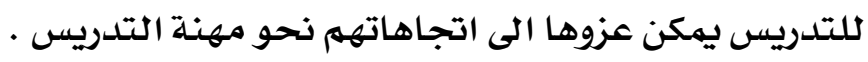

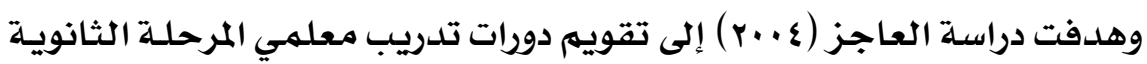

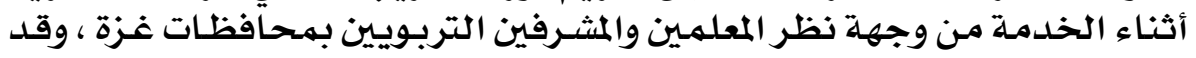

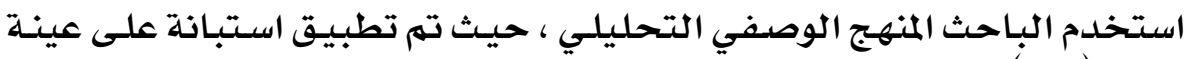

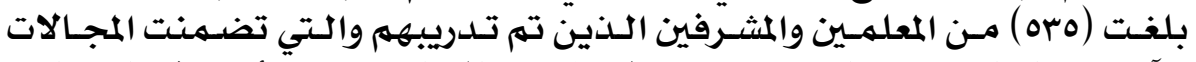

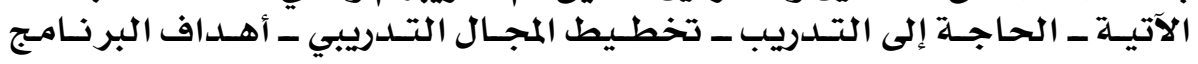

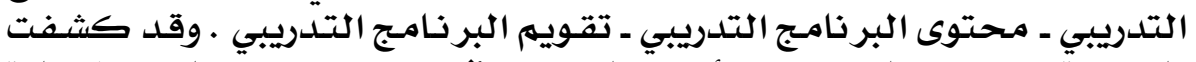

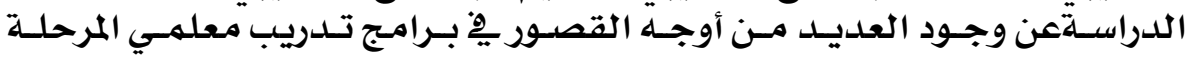

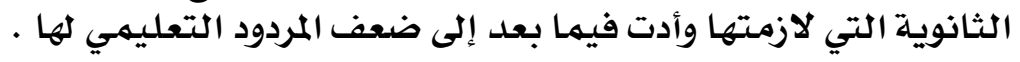

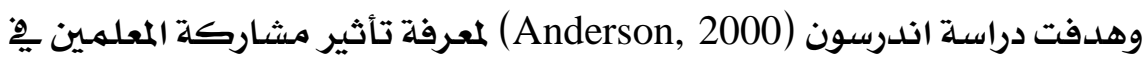

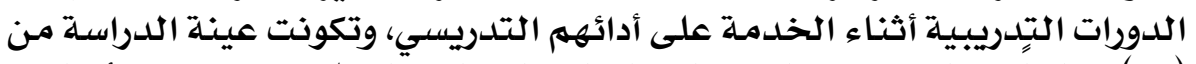

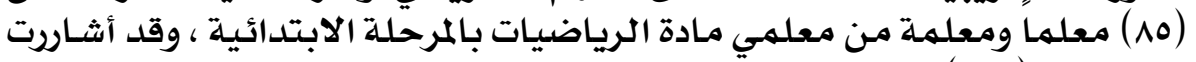

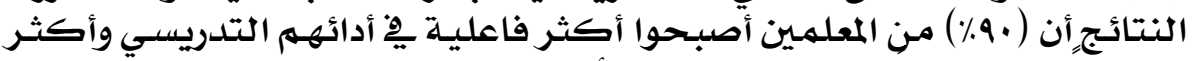

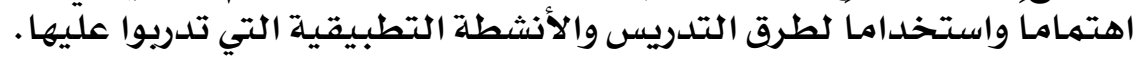

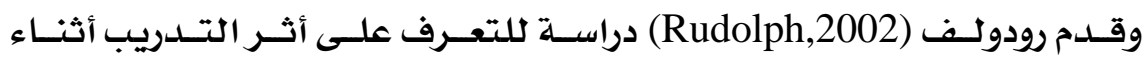

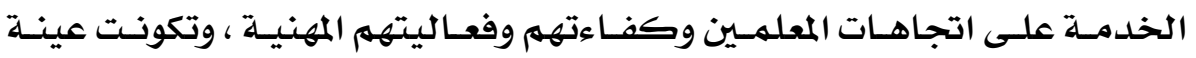

\section{rar}




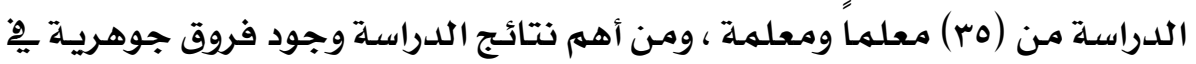

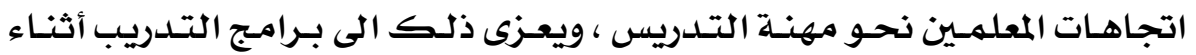

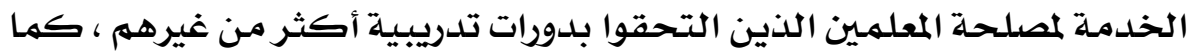

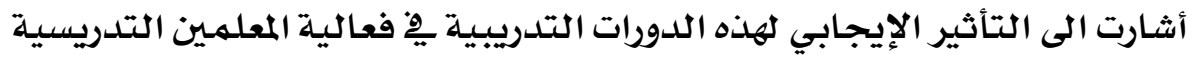

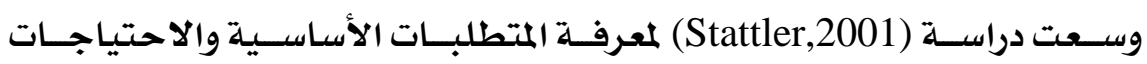

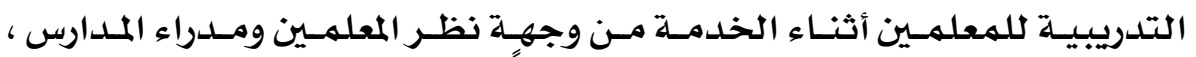

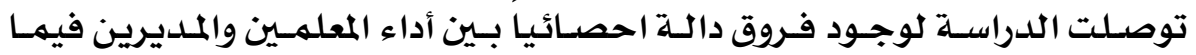

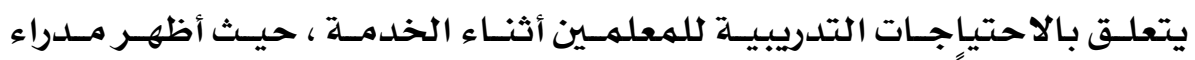

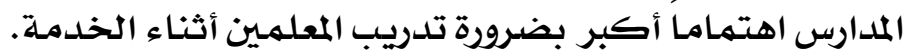

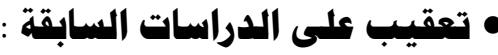

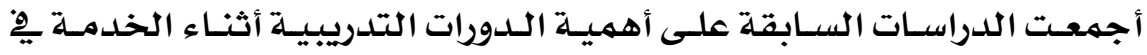

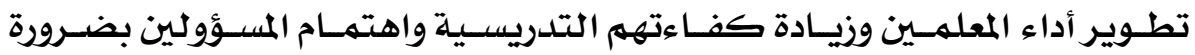

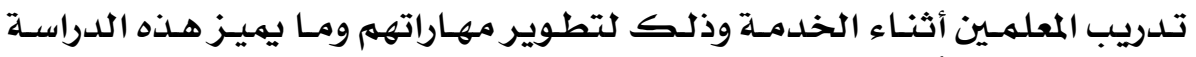

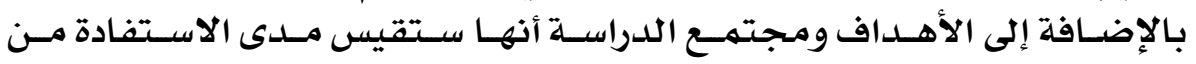
الدورات التدريبية من وجهة الإهـ نظر المعلمات التهات أنفسهن.

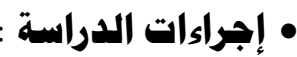

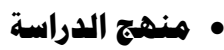

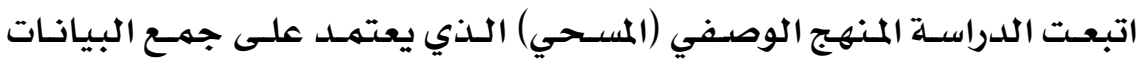

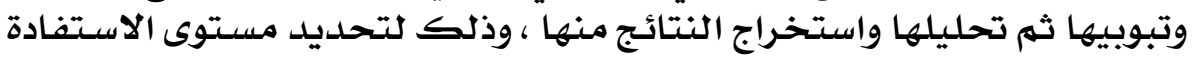

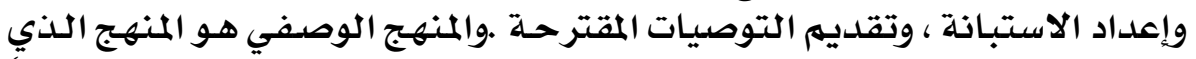

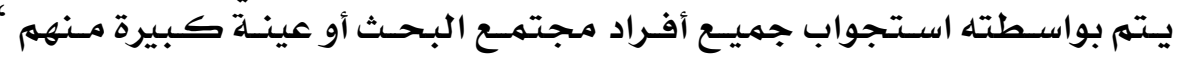

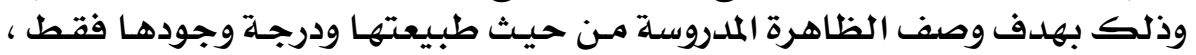

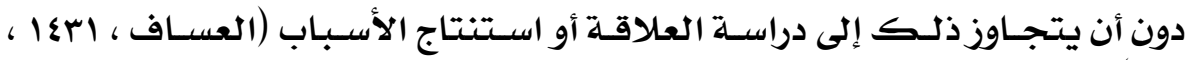
. (rr.

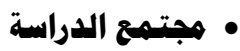

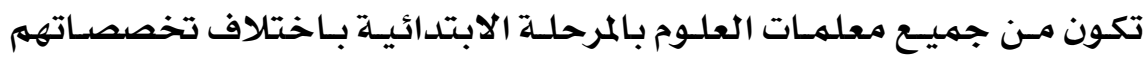

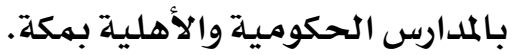

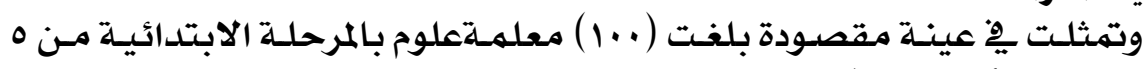

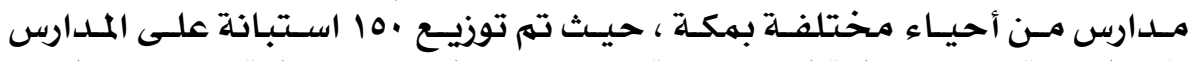

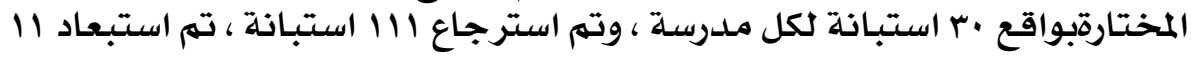

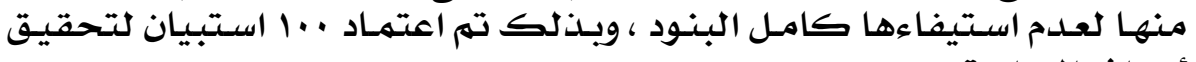

\section{rqu}




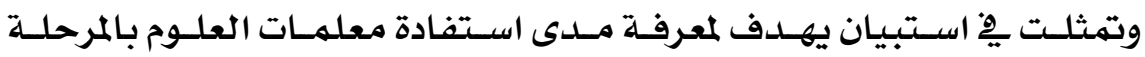

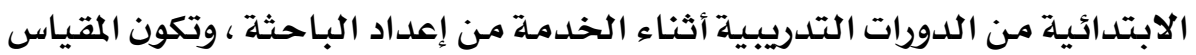

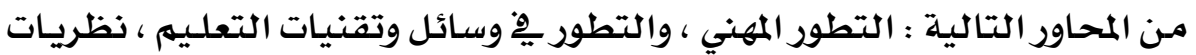

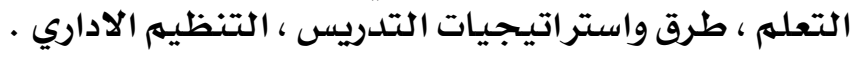

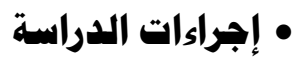

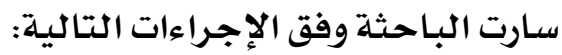

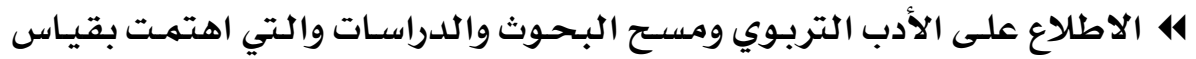

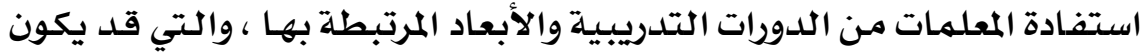

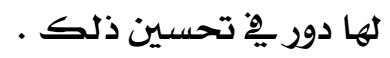

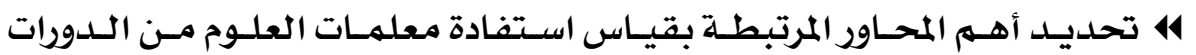

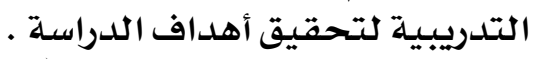

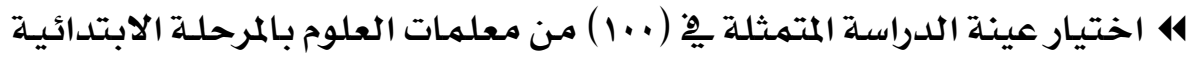

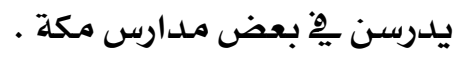

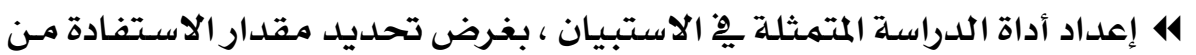

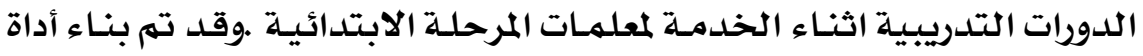

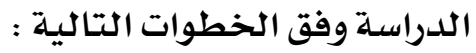

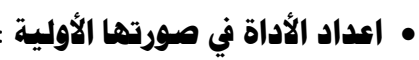

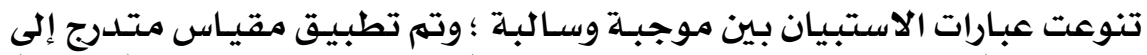

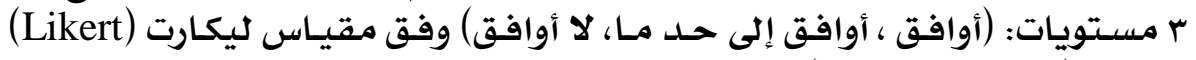

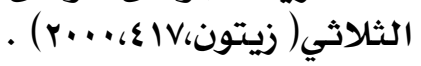

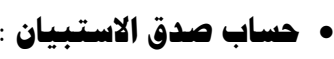

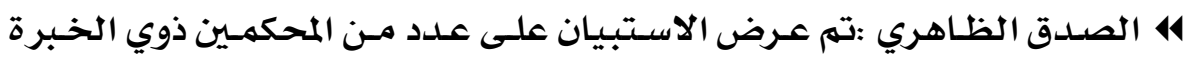

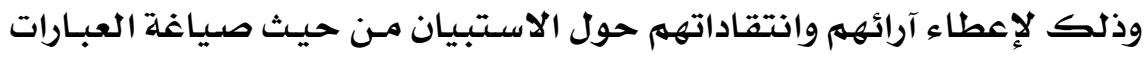

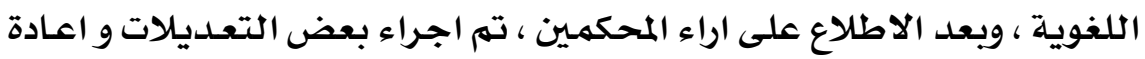

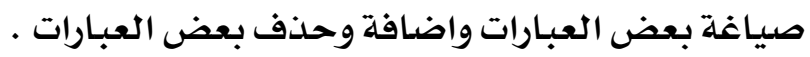

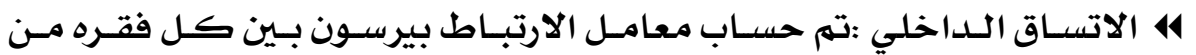

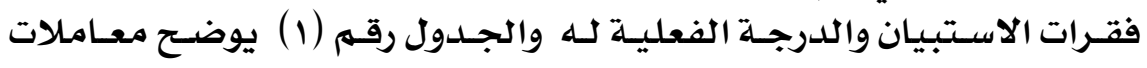
الارتباط.

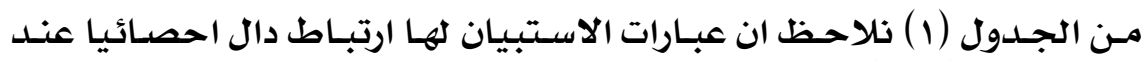

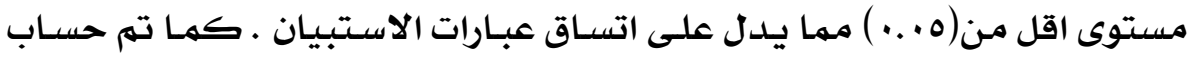

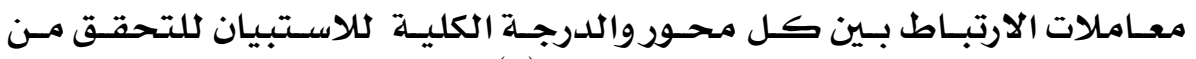

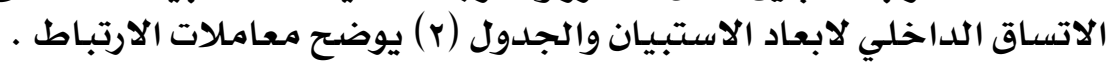

\section{rq\&}




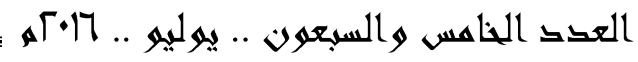

جدول (1) معاملات ارتباطات بيرسون

\begin{tabular}{|c|c|c|c|c|c|c|c|}
\hline الارتباط & العبارة & الارتباطل & العبارة & الارنباط & العبارة & الارنباط & العبارة \\
\hline .491 & 00 & $.771^{\prime \prime}$ & $T V$ & .624 & 19 & $.544^{\prime \prime}$ & 1 \\
\hline $.607^{\prime \prime}$ & 07 & .271 & $\overline{r A}$ & $.802^{*}$ & T. & $.671^{\circ}$ & $\bar{T}$ \\
\hline $.487^{\prime \prime}$ & OV & $.678^{*}$ & 19 & $.485^{\prime \prime}$ & YT & $.649^{\prime \prime}$ & $r$ \\
\hline $.508^{*}$ & 01 & $.619^{\prime \prime}$ & $\xi$ & $.637^{*}$ & $\overline{Y Y}$ & $710^{\prime \prime}$ & $\varepsilon$ \\
\hline $.799^{\prime \prime}$ & 09 & $.690^{\circ}$ & «ा & .768 & Tr & .550 & 0 \\
\hline $.647^{\prime \prime}$ & 7. & $722^{\prime \prime}$ & $\sum Y$ & $.625^{\prime \prime}$ & $T \xi$ & $.744^{\circ}$ & 7 \\
\hline \multirow[t]{12}{*}{.746} & $\pi$ & $.641^{\prime \prime}$ & $\varepsilon r$ & .738 & YO & .770 & $\bar{V}$ \\
\hline & & $.716^{\prime \prime}$ & $\xi \xi$ & $.710^{*}$ & rT & $.812^{\prime \prime}$ & $\lambda$ \\
\hline & & $.690^{\prime \prime}$ & $\leqslant 0$ & .615 & $T V$ & $.599^{\circ}$ & 9 \\
\hline & & $.724^{\prime}$ & $\sum 7$ & .728 & $T_{\lambda}$ & $.649^{\circ}$ & 1. \\
\hline & & $.768^{\prime \prime}$ & $\sum V$ & $.514^{\prime \prime}$ & rq & $.907^{\circ}$ & $\pi$ \\
\hline & & $.745^{\prime \prime}$ & $\sum \lambda$ & $.709^{\prime \prime}$ & $r$. & $.737^{\circ}$ & IT \\
\hline & & $743^{\prime \prime}$ & $\leqslant 9$ & .422 & $T$ & $.671^{\prime \prime}$ & $\pi$ \\
\hline & & $.627^{*}$ & 0. & .224 & TY & $.409^{\prime \prime}$ & $1 \varepsilon$ \\
\hline & & $.544^{*}$ & 01 & .606 & $r r$ & $.721^{*}$ & 10 \\
\hline & & $.552^{\prime \prime}$ & OY & .674 & $\Gamma \xi$ & .846 & 17 \\
\hline & & $.465^{\circ}$ & Or & $.739^{\prime}$ & TO & $.850^{\circ}$ & IV \\
\hline & & $.599^{\prime \prime}$ & $0 \leqslant$ & $.636^{\circ}$ & $r 7$ & $.677^{\circ}$ & 11 \\
\hline
\end{tabular}

0.01 ** رتباط مهم على مستوى

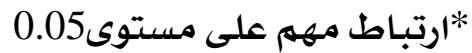

جدول (r) الاتساق الداخلي لابعاد الاستبيان

\begin{tabular}{|c|c|c|}
\hline معامل الارتباط & 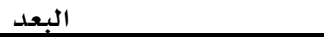 & م \\
\hline .885 & التطور المهني & \\
\hline .906 & التطور فِ تقنيات التعليهم & r \\
\hline .920 & نظريات التعله & $\underline{r}$ \\
\hline .941 & طرق واستراتيجيات التـدريس & $\underline{\varepsilon}$ \\
\hline .695 & التنظيهم الاداري & 0 \\
\hline
\end{tabular}

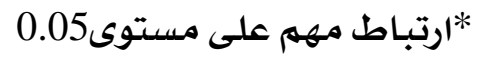

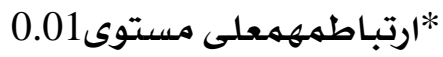

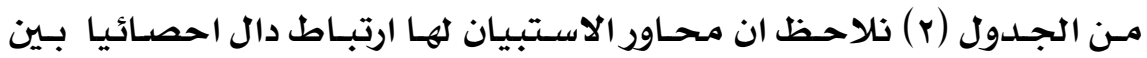

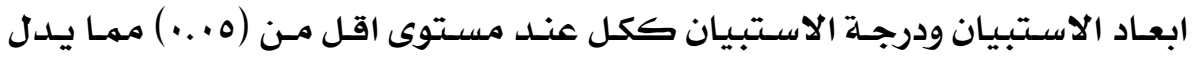
على اتساق محاور الاستبيان.

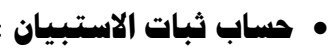

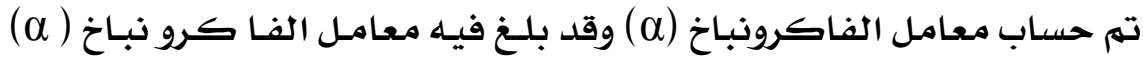

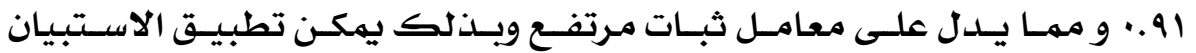

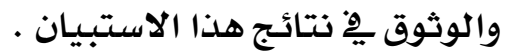

\section{rqo}




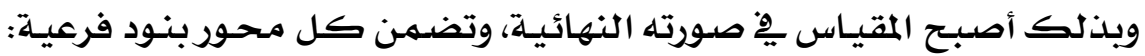

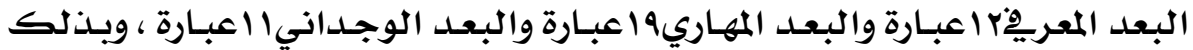

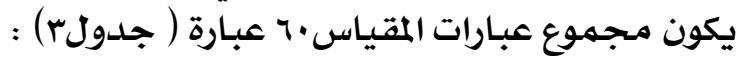

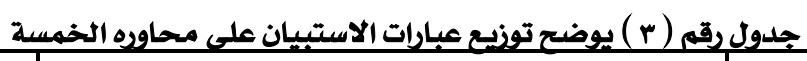

\begin{tabular}{|c|c|c|c|}
\hline العبارات & التعريف & المحور & م \\
\hline 1. من ' & 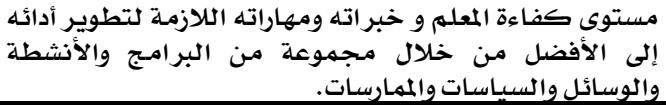 & التطور المهني & 1 \\
\hline من & وأجهزئم وادوات ومواد يستتخدمها المعلم لتحسين عملية التعليم & تقنيـات التعليهم & r \\
\hline من דr _r & 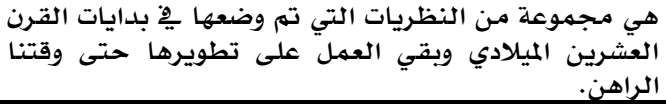 & نظريات التعلهم & $r$ \\
\hline من ·ع _ م & 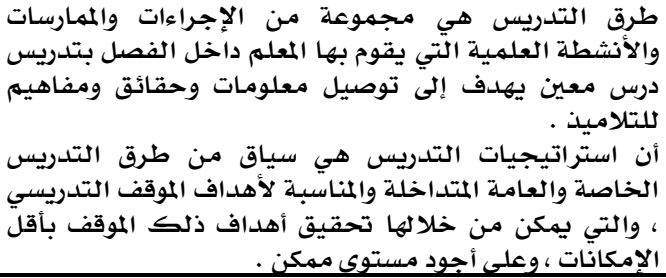 & طرقتراتيات & $\varepsilon$ \\
\hline من 1. & الهدف التوزيع المناسب للواجبـات والمسؤوليات من اجل تحقيق & الادداريى التنيم & 0 \\
\hline 7. & المجمـ- & & \\
\hline
\end{tabular}

• الإجابة على الأسئلة الدراسة :

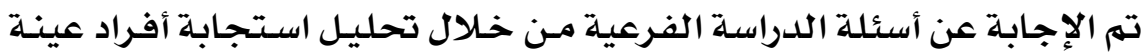

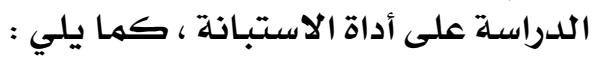

\section{• الإجابة على السؤال الأول للدراسة :}

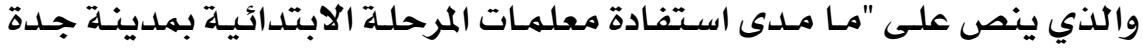

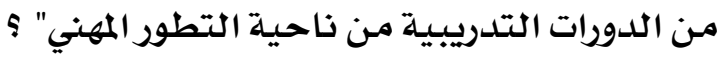

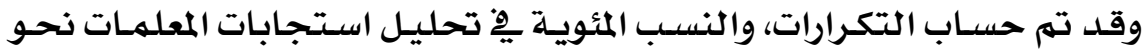

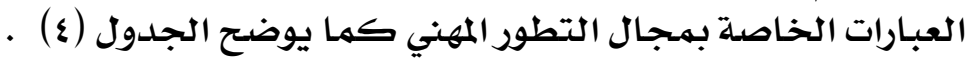

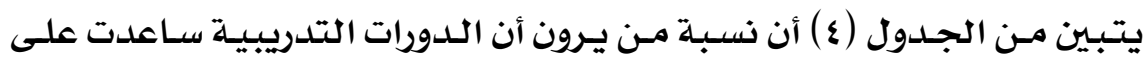

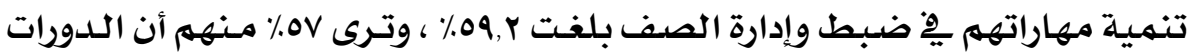

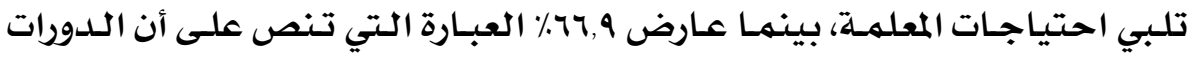

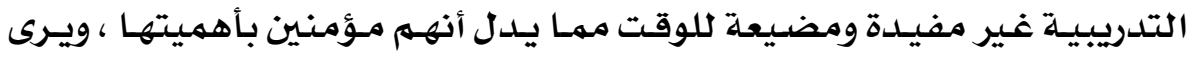

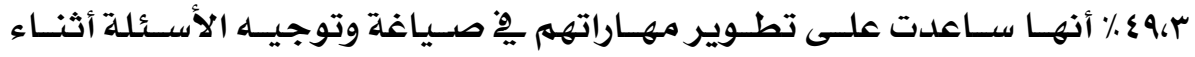

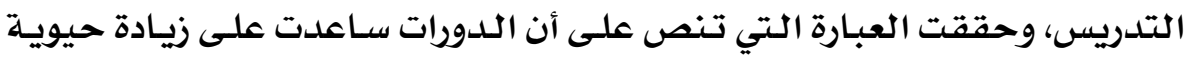

\section{rq7}




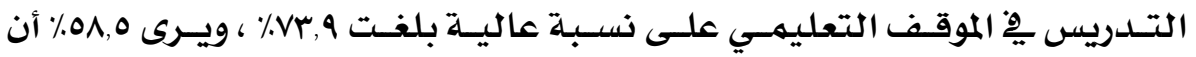

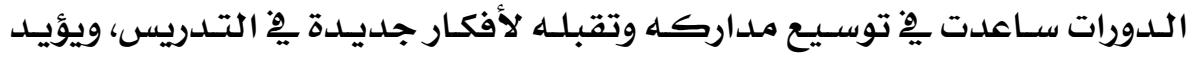

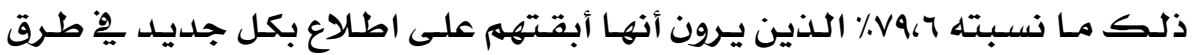

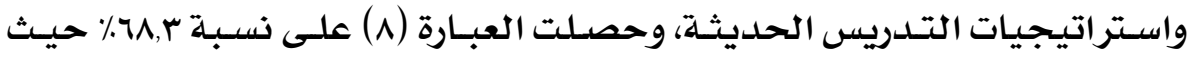

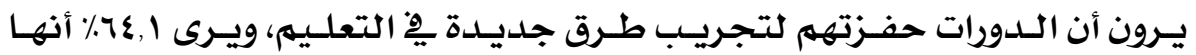

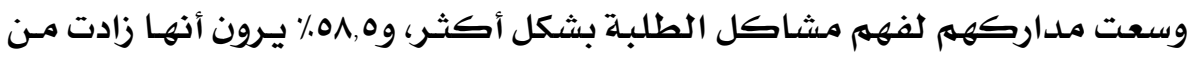

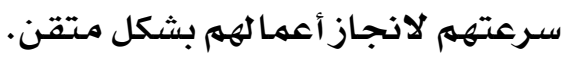

جدول (ع) استجاباتمعلمات العلوم بمحور التطور المهني

\begin{tabular}{|c|c|c|c|c|}
\hline غير موافق & موافق لحد مـا & 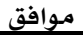 & العبارة & م \\
\hline$\%, 7$ & $\%$ ro,r & $\% .09, \mathrm{r}$ & نهت مهاراتي على ضبط وإدارة الصف & 1 \\
\hline$\%$ V & $\%$ \%৭, १ & $\% 1 r, \varepsilon$ & لا تلبى احتياجـات المعله & r \\
\hline$\% 77,9$ & $\%$ \% $\{, 7$ & $\%, 0$ & غير مفيدة ومضيعة للوقت & $r$ \\
\hline$\%$ \%, r & $\%, Y \wedge, r$ & $\%$ YY,O & لهم تطور مهارتى ِِْ صياغة وتوجيه الأسئلة أثناء التدريس & $\varepsilon$ \\
\hline$\%, \uparrow, \Lambda$ & $\%$ rr, r & $\% v r, q$ & سـاعدتنى على زيـادة حيويـة التدريس ِِِ الموقف التعليمي & 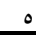 \\
\hline$\% .0 \wedge, 0$ & $\%$ \%ฯ, & $\% 10,0$ & لهم تسـاهم ِِ توسيع مداركى لأفكار جديدة فِ التدريس & 1 \\
\hline$\% \varepsilon, 9$ & $\% 10,0$ & $\% \vee ৭, 7$ & أبقتنى على اطلاع على طرق واستراتيجيات التدريس الحديثة & $\mathrm{v}$ \\
\hline$\%$ \%,r & $\%$ Y 1,1 & $\% 1 \cdot, 7$ & له تحفزني لتجريب طرق جديدة يِ التعليه & $\Lambda$ \\
\hline$\%, 4$ & $\% \cdot r \cdot r$ & $\%$ \% & وسعت مداركي لفهم مشاكل الطلبة ششكل أكثر & 9 \\
\hline$\%, 9,9$ & $\%$ & $\% ० \wedge, 0$ & زادت مـن سـرعتى يِّ انجـاز عملى بشكل متقن & 1. \\
\hline
\end{tabular}

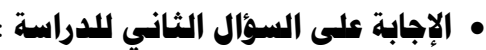

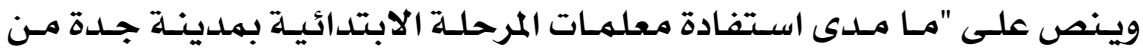

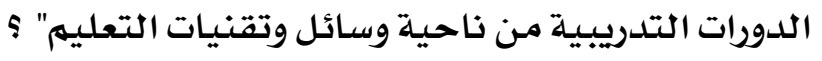

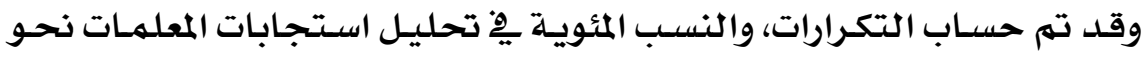

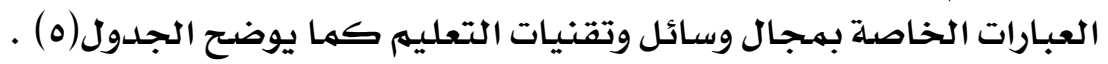

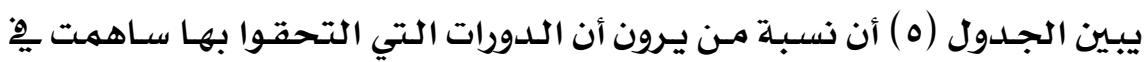

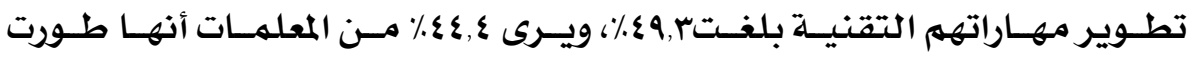

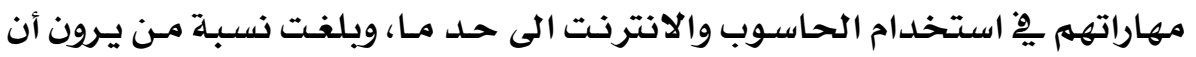

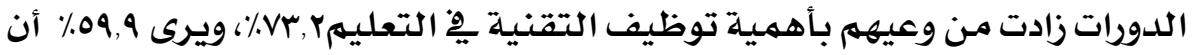

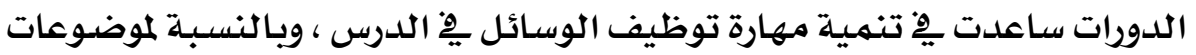

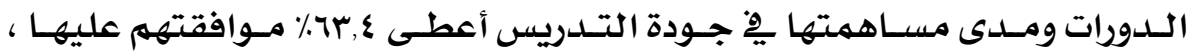

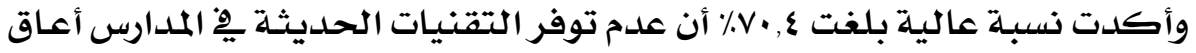

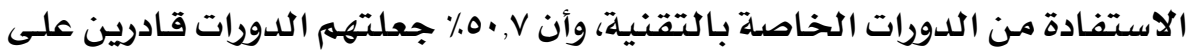

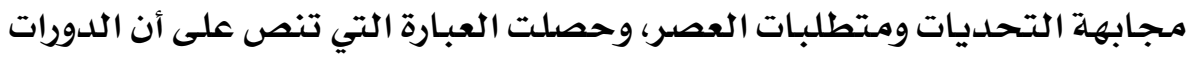

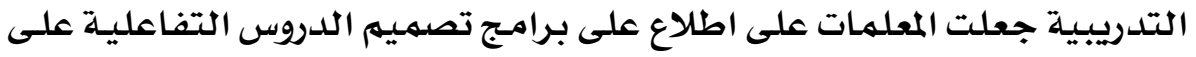

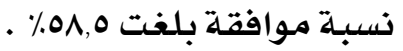

\section{rav}


العقد الخاهس والسبعهون .. يوليه .. 17•؟م

جلدول (0) استجابات معلمات العلوم بمحوروسائل وتقنيات التعليم

\begin{tabular}{|c|c|c|c|c|}
\hline غير موافق & موافق لحد مـا & 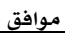 & 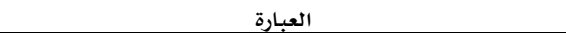 & م \\
\hline$\%$ \%, r & $\%$ \% & $\% १ \wedge, r$ & التقنية بدرجه التدريبية التي التحقت بها لم تساهم هِّ تطوير مهاراتي & 1 \\
\hline$\%$ \% r & $\%$ \% \& & $\% r v, r$ & طورت مهاراتي ِِّ استخدام الحاسوب والانترنت & r \\
\hline$\% 0,1$ & $\%$ \% 1,1 & $\%(r, r$ & زادت من الوعي بأهمية توظيف التقنية يِّ التعليم & r \\
\hline$\%$ \%, १ & $\%$ \% & $\%, 0$ & له تنهى لدي مهارة توظيف الوسائل ِِِ الدربس & $\varepsilon$ \\
\hline$\% \mathrm{~V}, \mathrm{~V}$ & $\% \curlyvee \wedge, q$ & \% & إن موضوعات الدورات التدريبية ساهمت فِ جودة التدريس & 。 \\
\hline$\%$ & $\%$ & $\% 17,9$ & لهم تساهم ِِّ تطوير مهاراتى ِِ استخدام الحاسب & 1 \\
\hline$\%$., 0 & $\%$ & $\% \cdot, 7$ & ساعدت بأن يكون المعلم على دراية بتشغيل الوسيلة المراد & $v$ \\
\hline$\%$ & \% & $\%$ \%,$q$ & ساعدت بأن يكون المعلم على دراية بصيانة وسائل التعليهم & $\wedge$ \\
\hline$\%$ & $\%$ \% १, & $\% 1 \cdot, 1$ & له تنهي لدي مهارة توظيف التقنية بالتعليم & 9 \\
\hline$\%$ & $\%$ \% & $\% \cdot 0 . \mathrm{V}$ & جعلتني قادرة على مجابهة التحديات ومتطلبـات العصر & 1. \\
\hline$\% 9,9$ & $\% 19, \mathrm{~V}$ & $\% \cdot, \xi$ & 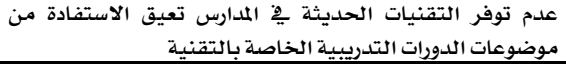 & 11 \\
\hline$\%, 0$ & $\%$ \% r,r & $\%$ \%, r & ساعدتنى يْ جعل بيئة الصف بيئة تعلم ديناميكية & ir \\
\hline$\% 00,1$ & $\%$ & $\%, r, \mathrm{~V}$ & له تساهم ِِّ تطوير مهاراتى ِِّ كيفية اختيار الوسيلة المناسبة & ir \\
\hline$\%, 0$ & $\%$ rr, 1 & $\%, 01,0$ & التفاعلية على اطلاع على الجديد ِِّ برامج تصميه الدروس & Iई \\
\hline$\%$ & $\%$ & $\%, 0$ & لهم تمكنى من استخدام وسائل التقنية يِّ التعليه & 10 \\
\hline
\end{tabular}

• الإجابة على السؤال الثالث للدراسة :

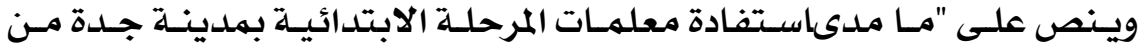

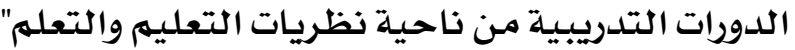

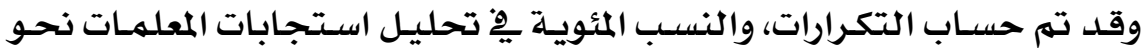

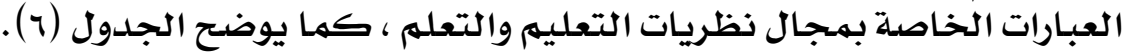

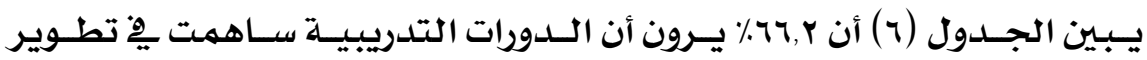

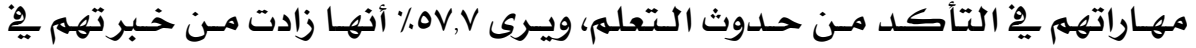

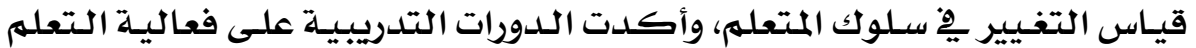

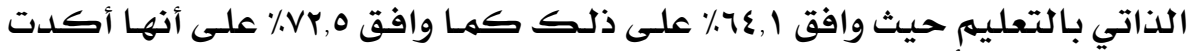

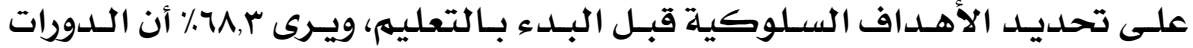

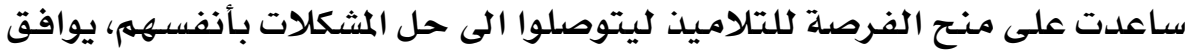

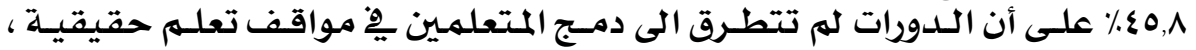

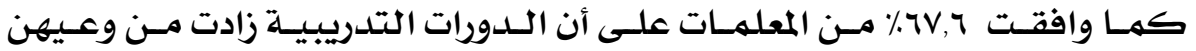

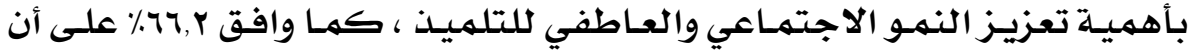

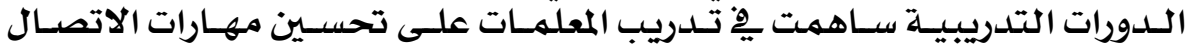

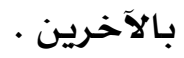

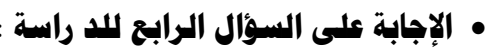

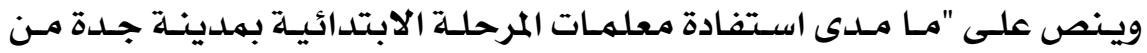

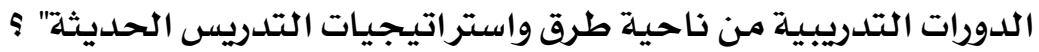

\section{ra^}




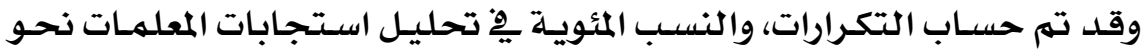

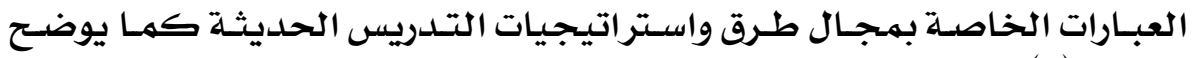

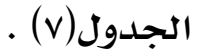

جدول (7) استجابات معلمات العلوم بمحور نظريات التعلم

\begin{tabular}{|c|c|c|c|c|}
\hline غير موافق & موافق لحد مـا & 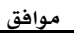 & 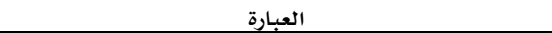 & م \\
\hline$\%$ & $\% r \cdot r$ & $\% \pi 7, r$ & ساهمت ِِّ تطوير قدراتي ٌِِ التأكد من حدوث التعلهم & 1 \\
\hline$\% \mathrm{v}, \mathrm{V}$ & $\% r \cdot r$ & $\% 1 r$ & لثم تزيد من خبرتي فِ قياس التغيير ِِّ سلوك المتعلم & r \\
\hline$\%$ & $\%$ \% १, & $\%(\varepsilon, 1$ & أكدت على فعالية التعلهم الذاتى بالتعليه & $r$ \\
\hline$\%$ & $\%$ \%r,q & $\%$ \%, 0 & أكالتعليه على أهمية تحديد الأهداف السلوكية قبل البدء & $\varepsilon$ \\
\hline$\%$ \%,r & $\% \mathrm{rV}, 0$ & $\%$ \%,r & أكشكلات بأنفى أهمية منح الفرصة للتلاميذ ليتوصلوا لحل & ○ \\
\hline$\% 00,7$ & $\%$ & $\%$ & للم تؤكد على ضرورة ربط المعلومات بحياة وخبرات التلاميذ & 1 \\
\hline$\%, r, v$ & $\%$ \%r, & $\%$ or,o & أكدت على التعلم لا التدريس & $\checkmark$ \\
\hline$\%$ & $\%$ \%, 1 & $\% 19, v$ & لم تتطرق إلى دمـج المتعلمين ِِّ مواقف تعله حقيقية & $\wedge$ \\
\hline$\% \varepsilon, r$ & $\%$ \% & $\% .79$ & أكدت على تشجيع وقبول ذاتية المتعلهم ومبادراته & 9 \\
\hline$\% \varepsilon V, Y$ & $\%$ & $\% 17, \mathrm{r}$ & لم تساعدنى على فهـ الأدوار الأخرى للمعلهم & 1. \\
\hline$\% \mathrm{~V}, \mathrm{~V}$ & $\%$ \%,० & $\% \cdot \cdot, \mathrm{V}$ & زادت من وعيب وثقتي بقدرات التلاميذ ومساعدتهم على تحديد & 11 \\
\hline$\%, 1$ & $\%$ \% , & $\% \mathrm{TV}, \mathrm{T}$ & زادت من وعيي بأهمية تعزيز النمو الاجتماعي والعاطفي & ir \\
\hline$\%$ \%r, & $\% r \cdot r$ & $\%$ \% & لهم تساعدنى على فهـه حاجـات المتعلمـين & ir \\
\hline$\%$ & $\% \curlyvee \vee, 0$ & $\% \pi 7, r$ & دربتنى على تحسين مهارات الاتصال بالآخرين & $1 \varepsilon$ \\
\hline
\end{tabular}

جدول (v) استجابات المعلمات محور طرق واستراتيجيات التدريس

\begin{tabular}{|c|c|c|c|c|}
\hline غير موافق & موافق لحد مـا & 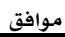 & 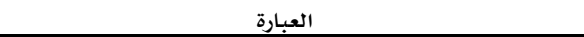 & م \\
\hline$\%$ or,1 & $\%$ \% & $\%, r, 1,1$ & تدور حول طرق واستر اتيجيات تدريس تقليدية & 1 \\
\hline$\%, r$ & $\%$ \% & $\%$ \% १, & مكنتنى من اختيار الاستراتيجية الأكثر مناسبة للموقف التعليمى & r \\
\hline$\%$ \%ฯ, & $\%$ \% & $\%$ \%r, , & تفتقر للتدريب العملي & r \\
\hline$\%$ & $\%$ \% & $\% \pi 1, r$ & علمتني كيفية توفير مناخ تعليمي يسمح بحرية التعبير والمناقشة & $\varepsilon$ \\
\hline$\%$ \%,r & $\%$ \% , , & $\% 17,9$ & ساعدتنى ِِ فهـم عملية التعله الذاتى والتعله التعاونى بالتعليم & $\bullet$ \\
\hline$\%$ \%,$Y$ & $\%$ \% & $\% 1 \leqslant, 1$ & له تكسبنى معارف وخبر ات ٍِِ الاستر اتيجيات الحديثة & 1 \\
\hline$\%(\bullet, \wedge$ & $\%$ \% & $\% 17, \mathrm{r}$ & صعبت على عملية التعليم & $\checkmark$ \\
\hline$\%$ & $\%$ & $\%$ \%r,V & علمتنى توظيف استر اتيجيات التدريس بشكل صحيح & $\wedge$ \\
\hline$\%$ & $\% \cdot r \cdot r$ & $\%$ r., & صححت بعض المفاهيم الخاصة بطرق التدريس & 9 \\
\hline$\%\{\Lambda, 7$ & $\%$ \% & $\%, 1 r, \varepsilon$ & لهم تكسبنى الكثير من الخبر ات ِِ استخدام الاستراتيجيات الحديثة & 1. \\
\hline$\%, \mathrm{Y}, \mathrm{\Lambda}$ & ו וץ/ & $\% \pi, Y$ & نهت مفاهيه ومههارات المعلمـين بالمدرسـة لتفعيل التعلهم النشط & 11 \\
\hline
\end{tabular}

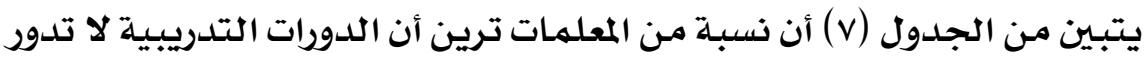

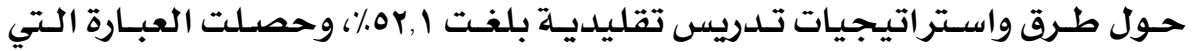

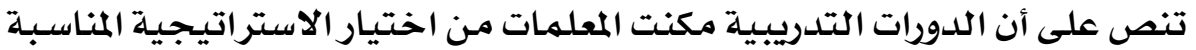

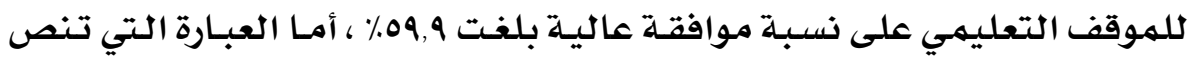

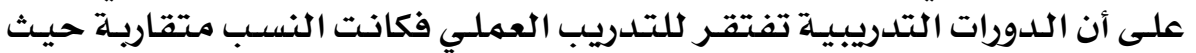

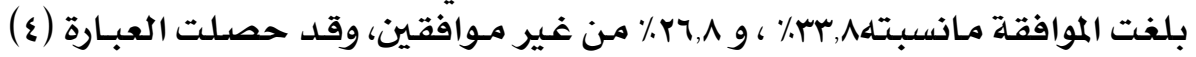




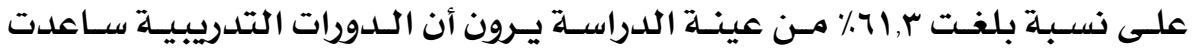

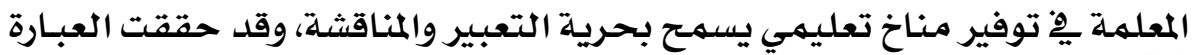

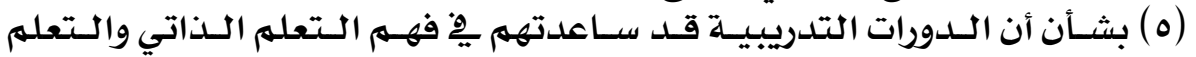

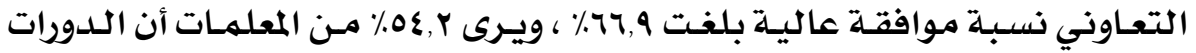

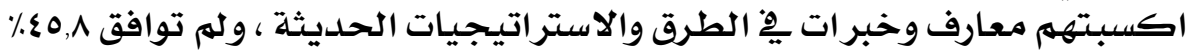

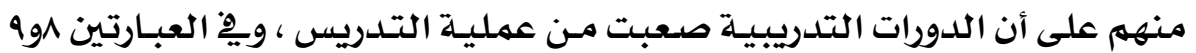

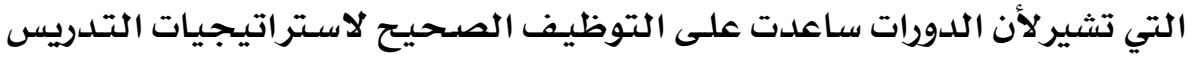

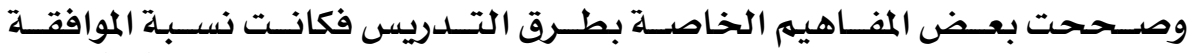

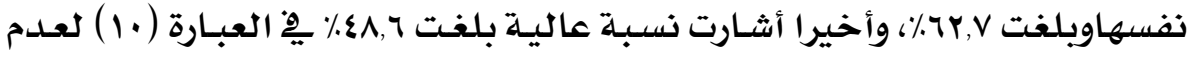

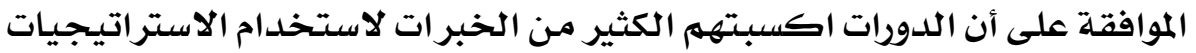

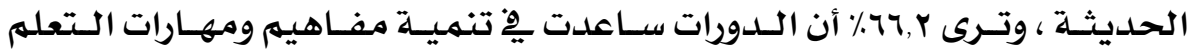
النشط.

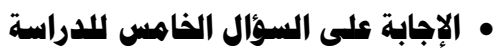

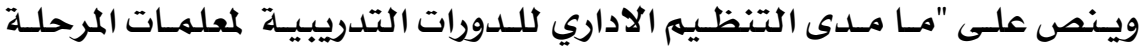

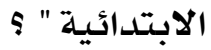

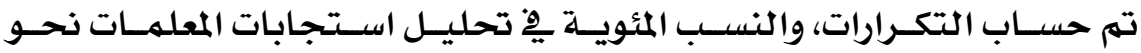

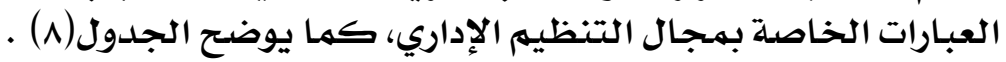

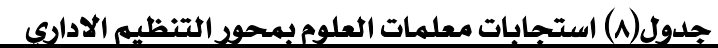

\begin{tabular}{|c|c|c|c|c|}
\hline 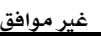 & موافق لحد مـا & 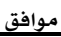 & 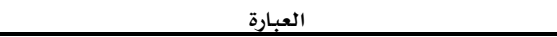 & \\
\hline$\% 1 r$ & $\%$ \%, 0 & $\%, 7,7$ & عدم توفر الحوافز المادية والمعنوية للمتدربين & 1 \\
\hline$\%$ \%., & $\% \varepsilon \wedge, 7$ & $\%$ & المدة الزمنية للدورات التدريبية مناسبة & r \\
\hline$\%$ \% & $\%$ \% & $\% 19, \mathrm{~V}$ & وقت الدورات التدريبية ملائمة للمعلميـن المتدربين & r \\
\hline$\% 17,9$ & $\%$ \%, & $\%$ \% , V & البر امـج المقدمة يِ الدورات التدريبية تناسب الواقع الفعلى للعمل & $\varepsilon$ \\
\hline$\%$ \%,r & $\% 0,9$ & $\% 1 \xi, \Lambda$ & المقدمـين للدورات التدريبية من غير المتخصصين & 0 \\
\hline$\% r \cdot r$ & $\%$ \% , & $\%$ \%,$\varepsilon$ & القاعات المخصصة للدورات التدريبية غير مناسبة & 7 \\
\hline$\%, r, v$ & $\% \varepsilon V, r$ & $\% \varepsilon \cdot 1$ & الإمكانيات الللازمة لإقامه الدورات التدريبية متوفرة & $\checkmark$ \\
\hline$\%$ \%,r & $\%$ & $\%$ \% r,v & المكان الذي تقام به الدورات التدريبية بعيد عن مكان عمل المعلمة & $\Lambda$ \\
\hline$\% 17, r$ & $\%$ & $\% \varepsilon \cdot \wedge$ & فرص تبادل الخبر ات بين المدرب والمتدربين قليلة & 9 \\
\hline$\%$ \%,० & $\%$ & $\%, r, \Lambda$ & موضوعات البر امج التدريبية غير مناسبة لواقع العمل & 1. \\
\hline$\%$ \%,$\vee$ & $\%$ & $\%$ \% १, & موضوعات البر اميج التدريبية تتصف بالتكرارووعدم التجديد & 11 \\
\hline
\end{tabular}

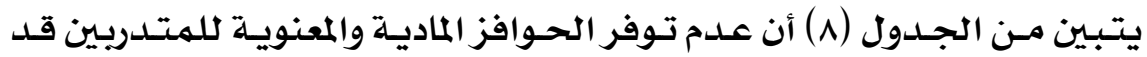

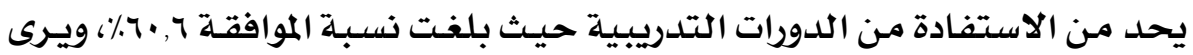

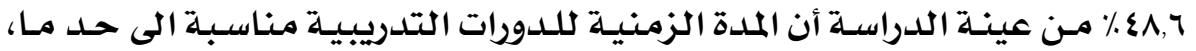

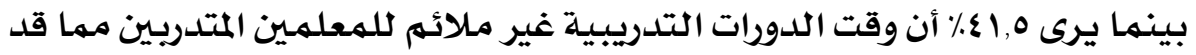

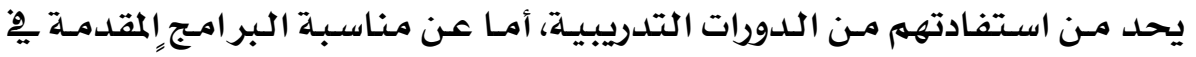

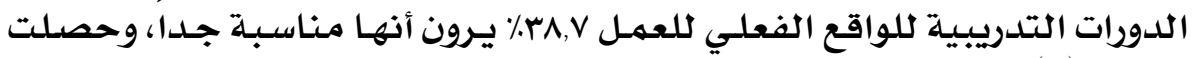

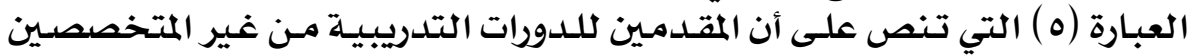

\section{$\varepsilon+$}




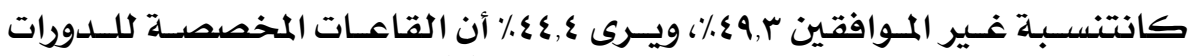

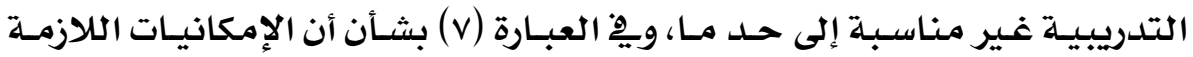

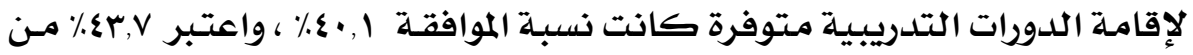

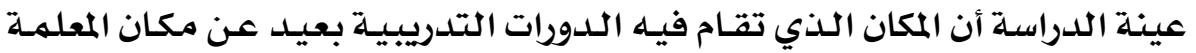

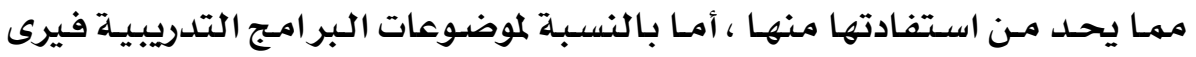

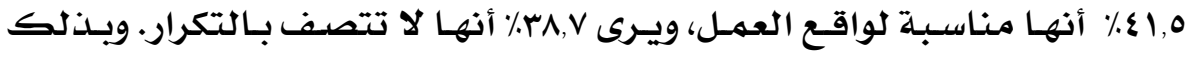

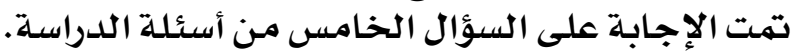

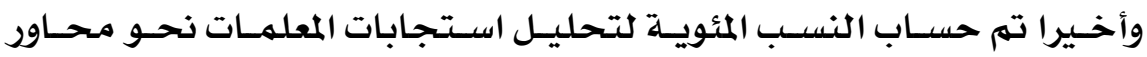

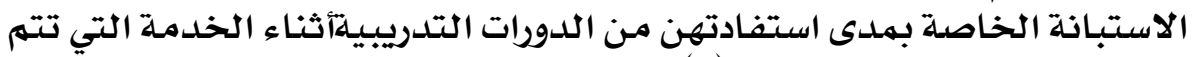

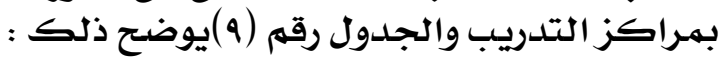

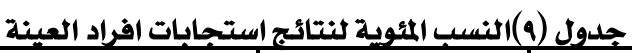

\begin{tabular}{|c|c|c|c|c|}
\hline غير موافق & موافق الى حد مـا & موافق & العنوان & المحور \\
\hline$\%$ & $\%$ \% . & $\% \varepsilon \cdot .0$ & & الاول \\
\hline$\%$ \%^.^ & \% & $\%$ \%q.r & & الثاني \\
\hline$\% \cdot r \cdot r \Lambda$ & דו.r.וז & $\%$ \& «.ro & & الثالث \\
\hline$\%$ \% $0 . \$ 0$ & $\% 1.41 .09$ & $\%$ \% r. \&० & & الرابع \\
\hline$\%$ \% . . . & $\%$ \%. ६० & \% & & الخامس \\
\hline \%.r.V.VY & 14. & $\% \varepsilon . .99$ & \multicolumn{2}{|c|}{ المجموع } \\
\hline
\end{tabular}

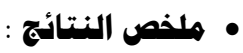

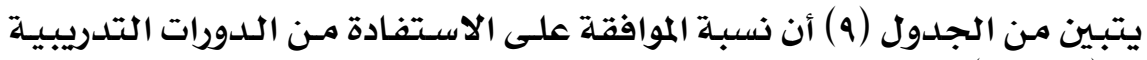

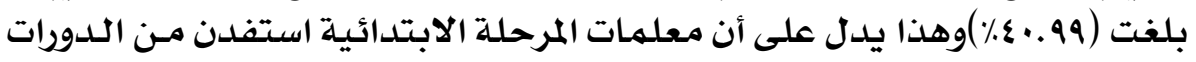

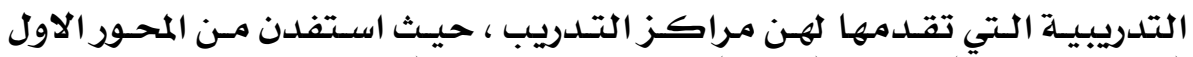

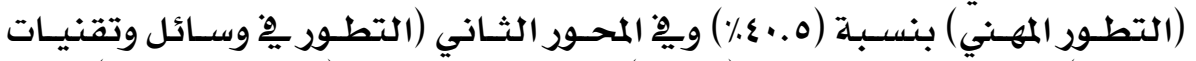

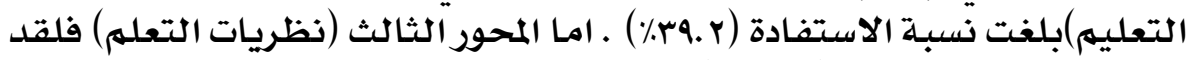

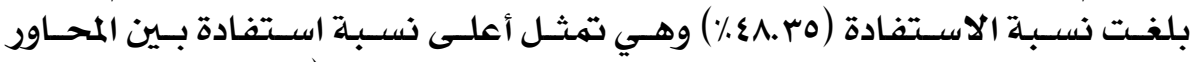

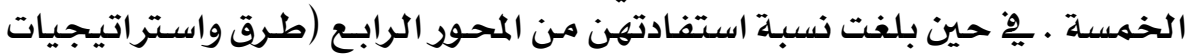

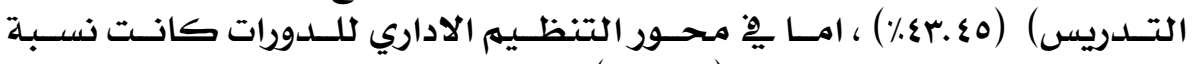

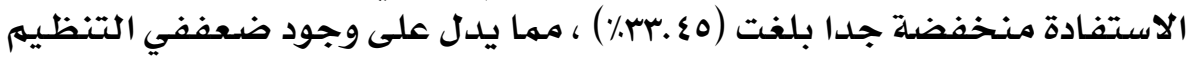

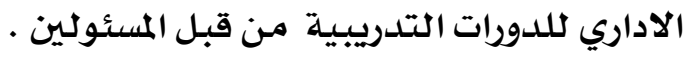

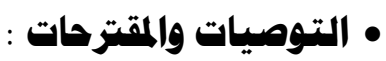

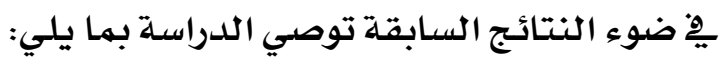

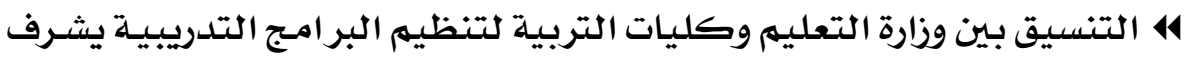

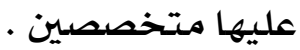

\section{$\varepsilon \cdot 1$}




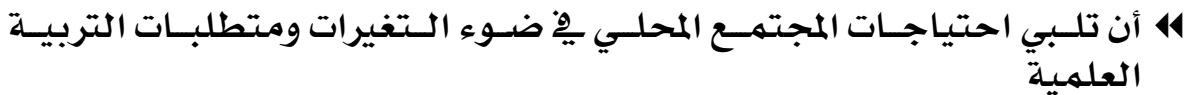

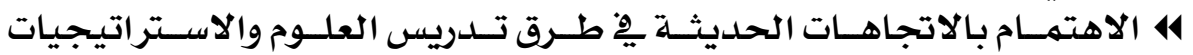

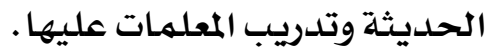

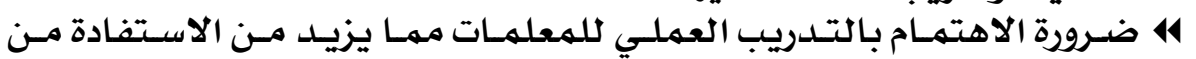
تلك الدورات.

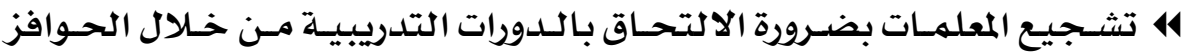
المادية والمعنوية. المعلية.

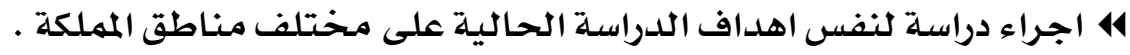

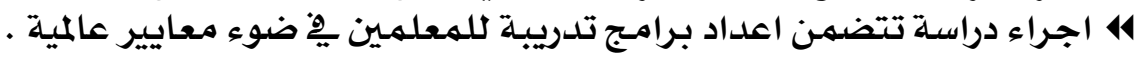

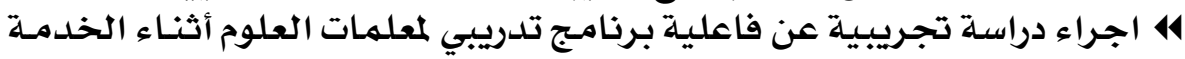

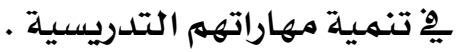

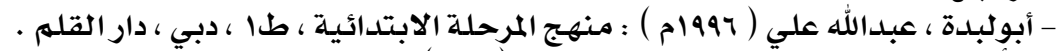

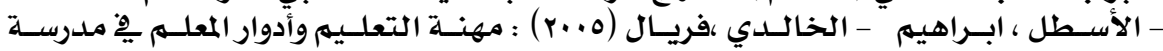

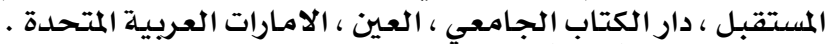

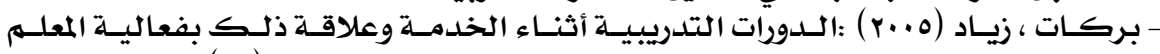

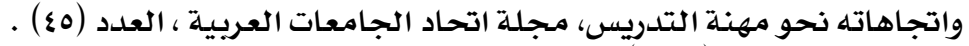

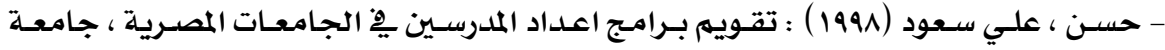

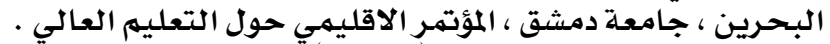

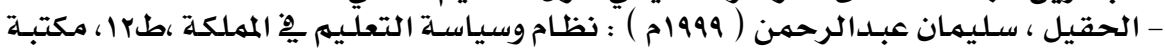

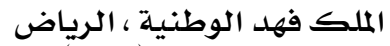

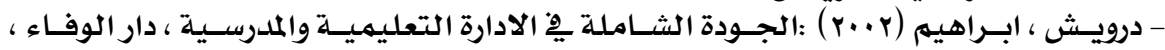

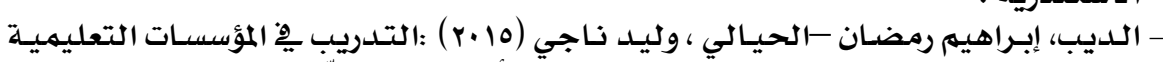

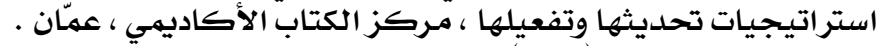

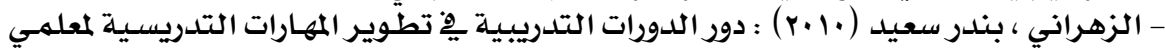

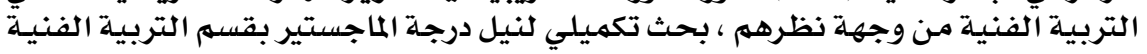

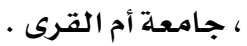

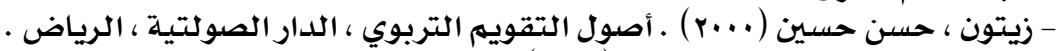

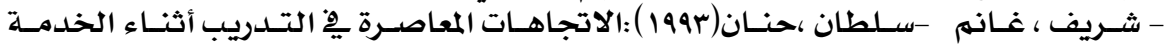

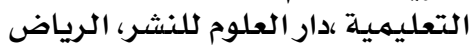

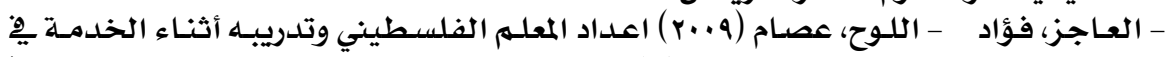

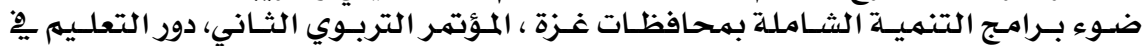

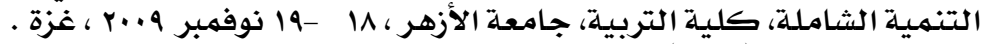

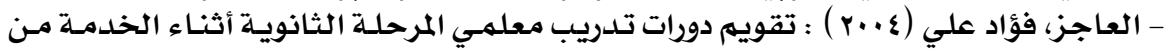

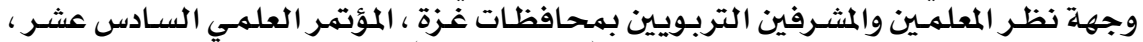

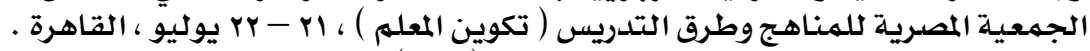

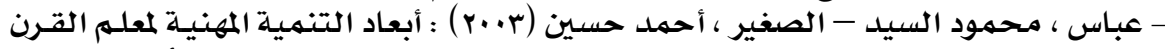

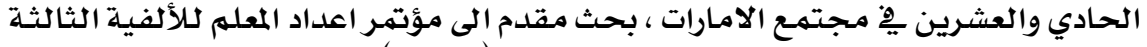

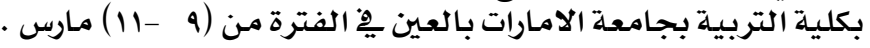

\section{$\varepsilon+Y$}




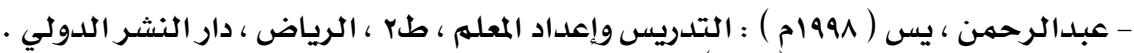

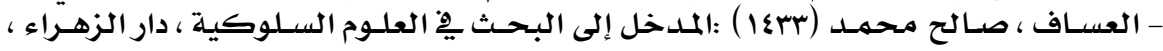

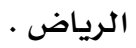

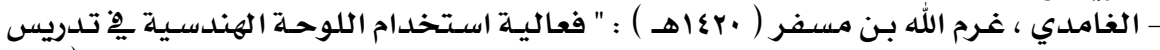

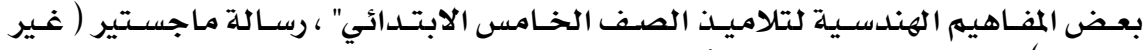

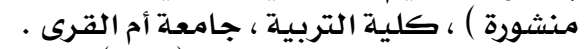

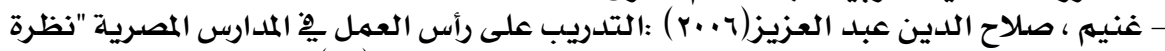

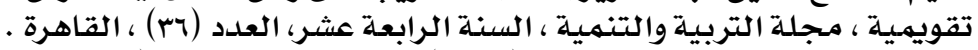

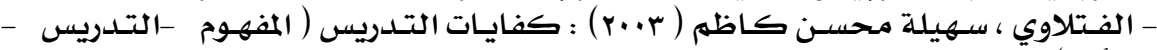

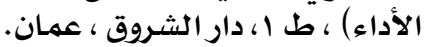

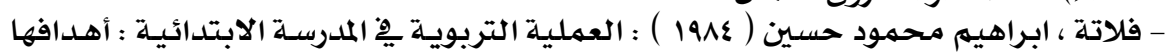

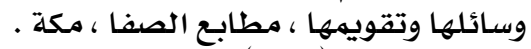

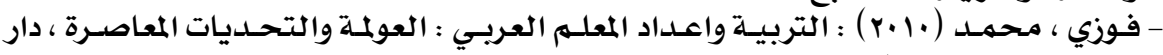

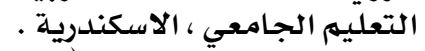

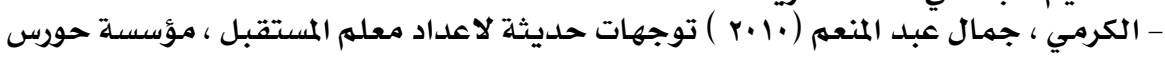

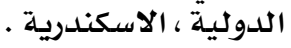

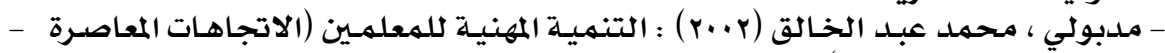

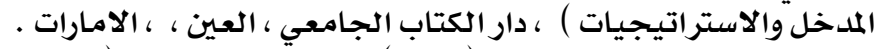

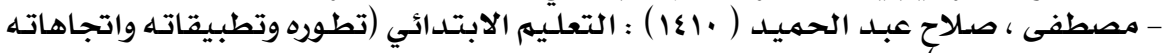

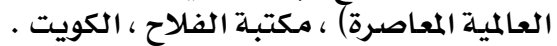

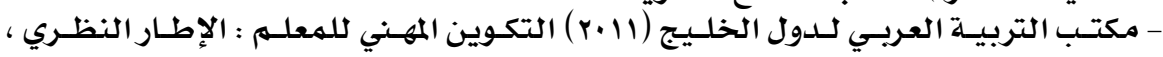

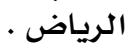

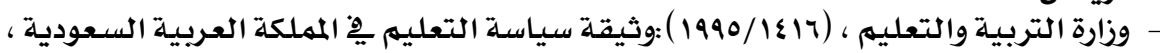

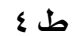
- وزارة التربية والتعليم (1914) ؛ واقع التربية واتجاهاتها ، المؤتمر العام الثامن لوزراء التربية

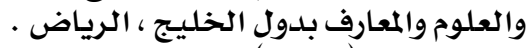

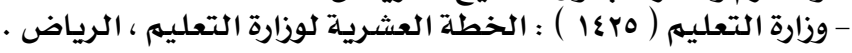

- Anderson , N (2000).Participatory approaches yo teacher training . Journal .Of Res. In Science Teaching, V. 11, N. 2 PP 144-166

- Rudolph , A . A (2002) "The effects of role - play as a a method in classroom management courses on in-service teachers 'attitudes and effectiveness" .ERIC , NO . AAC3055344

- Stattler , M.J (2001) " A Study of inservice training needs of teachers " .Dissr. Abstr.Iner, V.72, N .3

- Ohme,P.,\&Rayford,J.(2001).Hand.sonprofessionaldevelopment.Retr ievedMarch22,2003,fromhttp://www.physics.ohiostate.edu/ jossem/ REF/189.pdf\#search=\%22Georgia\%20Tech\%20GIFT\%20program $\% 22$.

\section{料溇溇溇将}

\section{$\varepsilon \cdot r$}

